DARIUSZ WOJNARSKI

https://orcid.org/0000-0003-0813-4874

Lublin

\title{
RZEMIOSŁO I HANDEL W KRASNYMSTAWIE. MIĘDZY PROSPERITY A KRYZYSEM (POŁOWA XVI-XVII WIEK)
}

Zarys treści: Kondycję krasnostawskiego rzemiosła i handlu od połowy XVI do XVII w. determinowały uwarunkowania o znaczeniu lokalnym, regionalnym i ogólnopolskim. Przywileje królewskie, dogodne położenie handlowe, korzystna koniunktura gospodarcza decydowały o rzemieślniczo-handlowym profilu Krasnegostawu w XVI w., choć symptomy spowolnienia wystapiły już w ostatnich dziesięcioleciach tego stulecia. W XVII w. nasilenie klęsk elementarnych, w tym wojen, rozrost jurydyk, konkurencja ze strony nowo lokowanych miast na czele z Zamościem oraz zmiany strukturalne w gospodarce Rzeczypospolitej stanowiły składowe przesłanek kryzysu. Jego apogeum, któremu towarzyszyła depopulacja, przypadło na lata siedemdziesiąte i osiemdziesiate XVII stulecia. Następstwem był spadek rangi Krasnegostawu do roli ośrodka agrarnego przy jednoczesnej marginalizacji handlu i rzemiosła. Wyhamowanie tych negatywnych tendencji obserwujemy w końcu tzw. srebrnego wieku.

The content outline: The condition of Krasnystaw's crafts and trade from the mid-sixteenth until the seventeenth century depended on local, regional, and national factors. Royal privileges, beneficial location on trade routes, and good state of the economy all determined the role of Krasnystaw as an artisan-commercial centre in the sixteenth century, although first harbingers of future crisis could already be noticed in the last decades of the century. In the seventeenth century, Krasnystaw's status was undermined by an accumulation of natural disasters and wars, growth of jurydykas, competition from newly chartered towns, most importantly Zamość, and structural changes in the Commonwealth's economy. The crisis saw its peak in the 1670s and the $1680 \mathrm{~s}$ and went hand in hand with the depopulation of the centre. As a result, Krasnystaw was demoted to an agricultural settlement and its trade and crafts became largely marginalised. This negative trend changed towards the end of the Commonwealth's "Silver Age." 
Słowa kluczowe: Krasnystaw, miasto, historia gospodarcza, handel, rzemiosło, gospodarka miejska, starostwo krasnostawskie, ziemia chełmska, kryzys XVII w.

Keywords: Krasnystaw, city, economic history, trade, crafts, municipal economy, Krasnystaw Starosty, Chełm Land, crisis of the seventeenth century

Celem artykułu jest przedstawienie sytuacji krasnostawskiego rzemiosła i handlu w perspektywie ok. 150 lat, kiedy obserwujemy zarówno przypadająca na pierwsze dziesięciolecia fazę pomyślności gospodarczej (prosperity), jak też późniejszą stagnację i regres wpisujące się w zjawisko kryzysu XVII w. Interesujący jest również ich potencjał, kondycja i specjalizacja zawodowa, z uwzględnieniem - tam gdzie jest to możliwe - powiazań z regionalnym i ogólnokrajowym rynkiem. Podstawowe założenie opiera się na zdefiniowaniu splotu wieloaspektowych uwarunkowań determinujących zamożność i możliwości rozwojowe miejskiej społeczności kupców i rękodzielników. Artykuł ma wykazać, w jakim stopniu i czy w ogóle takie czynniki, jak położenie miasta, przywileje królewskie, rosnąca aktywność ekonomiczna miejscowej szlachty, rozrost jurydyk oraz klęski elementarne w postaci wojen, pożarów czy epidemii wpłynęły na potencjał gospodarczy Krasnegostawu. To zadanie niełatwe, zwłaszcza że w zasadzie do dzisiaj nowożytny Krasnystaw nie był przedmiotem poważniejszego zainteresowania naukowego $\mathrm{w}$ aspekcie gospodarczym ${ }^{1}$. Tematyka jest ważna, chociażby dlatego, że dotyka jednego z najznaczniejszych i najstarszych ośrodków dawnej ziemi chełmskiej. Kluczowych informacji do analizy krasnostawskiego handlu i rzemiosła dostarczaja archiwalia skarbowe dawnej Rzeczypospolitej (lustracje, inwentarze, rejestry poborowe). Te ostatnie, ale głównie pochodzące z XVII w., kiedy często były sporządzane według tzw. starych kwitów, mają stosunkowo najniższą wartość. Jak ostatnio wykazał Krzysztof Boroda, nie można dezawuować zgłoszeń podatkowych $\mathrm{w}$ postaci abiurat, na które składały się odebrane zaprzysiężone zeznania (juramenty) ${ }^{2}$. Sporo rozproszonych wiadomości zawierają też księgi sądów szlacheckich, nieco akta miejskie oraz dyplomy władców

${ }^{1}$ Nieco miejsca problematyce zniszczeń wojennych w interesujacym nas okresie poświęcił J. Ternes, Ferro, igni et... peste. Zniszczenia wojenne i klęski elementarne $w$ Krasnymstawie $w 2$ potowie XVII wieku, „Zapiski Krasnostawskie” 4, 2013, s. 33-43. Z kolei w swoich notatkach (choć mało dokładnych) L. Bieńkowski zwrócił uwage m.in. na elementy stosunków handlowych i produkcyjnych, ale jego rozważania kończą się na XVI w.; Biblioteka Katolickiego Uniwersytetu Lubelskiego (dalej: BKUL), sygn. 2362.

${ }^{2}$ K. Boroda, Geografia gospodarcza Królestwa Polskiego w XVI wieku, Białystok 2016, s. 67-68. 
polskich. Uzupełnione informacjami z innych źródeł i literatury naukowej pozwalaja na pokazanie nieznanego dotychczas ważnego etapu rozwoju gospodarczego Krasnegostawu. Umożliwiają też udzielenie dość wyczerpującej odpowiedzi na pytanie o chronologię i czynniki sprawcze tzw. kryzysu XVII w. w średniej wielkości miastach królewskich.

\section{Tendencje rozwojowe do końca XVI w.}

Swój miejski byt Krasnystaw rozpoczą 1 III 1394 r. wraz z nadaniem przywileju lokacyjnego na prawie magdeburskim. Na mocy tego dokumentu król Władysław Jagiełło uposażył miasto w 100 łanów gruntów oraz zezwolił, by odbywać „targ cotygodniowy w każdy czwartek”3. Przestrzeń miejską z centralnie położonym rynkiem uzupełniała strefa podmiejska, gdzie - oprócz domostw - znajdowały się ogrody, gospodarstwa rolne mieszczan oraz niektóre zakłady przetwórstwa płodów rolnych, jak młyny, gorzelnie czy słodownie. Przedmieścia, z czasem bardzo rozległe, w sposób naturalny najbardziej rozwinęły się wzdłuż szlaków handlowo-komunikacyjnych prowadzacych przez przeprawy mostowe do trzech bram miasta (Chełmskiej, Krakowskiej i Lubelskiej). Nomenklatura ich poszczególnych części wywodziła się od pobliskich osad, folwarków oraz kierunków komunikacyjnych: Lubelskie, Zastawie, Zadworze, Zakościele, Piaski, Niemienickie, Krakowskie i Zakręcie ${ }^{4}$.

W analizowanym okresie Krasnystaw był centralnym punktem starostwa, do którego należały okoliczne osady tworzace zasobne zaplecze wiejskie (12-13 wsi). Do miasta w okresie targów i jarmarków podążano, aby sprzedać płody rolne i inwentarz oraz zaopatrzyć się w produkty rzemieślnicze. Handel i rzemiosło określały, podobnie jak w przypadku niektórych innych miast lokacyjnych, najważniejsze zajęcia miejskie, nota bene czynniki najbardziej sprzyjajace rozwojowi. U progu interesującego nas okresu dla większości mieszczan rolnictwo było uzupełniającym źródłem dochodów. Tylko dla 1/3 (łącznie z mieszkańcami przedmieść) stanowiło zaś podstawę egzystencji ${ }^{5}$. W kolejnych dekadach obserwujemy dynamicznie zmiany sektorowe w kierunku mniej korzystnej struktury społeczno-zawodowej.

${ }^{3}$ Przywilej lokacyjny miasta Krasnegostawu 1394 r., [oprac. W. Fedorowicz, A. Leńczuk], Krasnystaw 2014, s. 10-11.

${ }^{4}$ Wszystkie wymienione przedmieścia zorganizowano do końca XVII w., najwcześniej Zastawie, które łączyło się z terenami na grobli stawowej, gdzie pojawili się pierwsi osadnicy podmiejscy.

${ }^{5}$ BKUL, sygn. 2362, s. 75 . 


\section{Handel}

Handel w mieście staropolskim prowadzono w sklepach, karczmach, kramach i na przeznaczonych do tego wydzielonych placach. Dokument lokacyjny zezwolił na targach tygodniowych „wszystkim i poszczególnym kupcom na swobodę na nim sprzedawania i kupowania towarów i rzeczy, jakiegokolwiek będą rodzaju albo postaci, według ich upodobania"6. Można powiedzieć, że był to najważniejszy dzień w tygodniu dla całego miasta, czas wzmożonego ruchu skoncentrowanego na placu targowym. Oferujący swoje produkty musieli uiścić opłatę dla dzierżawcy podatku targowego, który w formie zryczałtowanej odprowadzał staroście krasnostawskiemu rocznie 15 lub 16 złp ${ }^{7}$. Już w XV w. w mieście odbywały się kilkudniowe jarmarki skorelowane z terminami świąt religijnych. Przypadały na dzień św. Kiliana (8 lipca) i św. Elżbiety (19 listopada). Zapewne nie były zbyt popularnie, ponieważ w 1565 r. przywilejem królewskim zostały przeniesione na święto Wniebowzięcia NMP (15 sierpnia) i Trzech Króli (6 stycznia) ${ }^{8}$. W nowym stuleciu starano się o kolejną zmianę terminów jarmarków, tym razem na dzień św. Michała (29 września) i Zielone Świątki (święto ruchome). Tę propozycję poparła szlachta, wstawiając się za mieszczanami krasnostawskimi na sejmiku chełmskim w 1633 r. ${ }^{9}$ Wiele przemawia za tym, że były to nieskuteczne próby przeciwdziałania kryzysowi miasta z uwagi na radykalne zmniejszenie transakcji handlowych, zwłaszcza artykułami rzemieślniczymi. Adam Manikowski zauważył, że jeszcze przed okresem wojen z połowy XVII w. daje się zauważyć spadek znaczenia jarmarków ${ }^{10}$. W miastach wielkości Krasnegostawu jarmarki, podobnie jak targi, miały jedynie lokalne znaczenie. Z drugiej strony - jak skonstatował Andrzej Wyrobisz - nawet $\mathrm{w}$ małych miastach zasięg oddziaływania terytorialnego jarmarków był większy i z tego tė̇ względu generowały one wyższe obroty handlowe w porównaniu do targów ${ }^{11}$.

${ }^{6}$ Przywilej lokacyjny..., s. 11.

${ }^{7}$ Lustracja województw ruskiego, podolskiego i betskiego 1564-1565, cz. 1, wyd. K. Chłapowski, H. Żytkowicz, Warszawa 1992, s. 6; Жерела до історї̈ України-Руси, t. 7, wyd. M. Грушевський, Lwów 1903, s. 2; AGAD, Archiwum Skarbu Koronnego (dalej: ASK), dz. LVI, sygn. 105, k. 64v.

8 MRPS, cz. 5: Sigismundi Augusti regis tempora complectens (1548-1572), t. 1: Acta cancellariorum 1548-1572, wyd. T. Wierzbowski, Varsoviae 1919, nr 3148, s. 182.

${ }^{9}$ Instrukcja, 25 VIII 1639 r., w: Akta sejmikowe ziemi chetmskiej 1572-1668, oprac. W. Bondyra, H. Gmiterek, J. Ternes, Lublin 2013, s. 213.

${ }_{10}$ A. Manikowski, Zmiany czy stagnacja? Z problematyki handlu polskiego $w$ drugiej połowie XVII wieku, PH, t. 64, 1973, nr 4, s. 786.

11 A. Wyrobisz, Handel w Solcu nad Wisła do końca XVIII w. Przyczynki do historii rynku wewnętrznego $w$ Polsce przedrozbiorowej, PH, t. 57, 1966, nr 1, s. 26. 
Rozwój gospodarczy Krasnegostawu wspierało jego dogodne położenie u zbiegu dróg lądowych i wodnych. Usytuowany nad rzeką Wieprz, która mniej więcej od tego miejsca była spławna, mógł korzystać z tego sposobu transportu towarów masowych. Krzyżowały się tutaj lądowe szlaki handlowe, co wpisuje się również $\mathrm{w}$ proces powstania miasta, zwiąany z okresem stabilizacji politycznej po zakończonych sukcesem czternastowiecznych zmaganiach wojennych o przyłączenie Rusi Czerwonej do Korony. Dzięki temu na znaczeniu zyskał międzynarodowy szlak handlowy znad Morza Czarnego do Gdańska ${ }^{12}$. Biegnący także przez ziemię chełmska, w drugiej połowie XIV w. był jedną z najważniejszych arterii drożnych państwa polskiego. Implikował rozwój wielu królewskich inicjatyw lokacyjnych, m.in. Lwowa (1356), Chełma (1392), Krasnegostawu (1394) czy Hrubieszowa (1400). W kolejnym stuleciu położenie handlowe miasta staje się mniej atrakcyjne, wiedzie tędy gościniec ze Lwowa ${ }^{13}$. Wyznaczenie tej trasy dla handlu ruskiego znajdujemy w przywileju Kazimierza Jagiellończyka z 1450 r., wówczas jej przebieg był następujący: Hrubieszów, Krasnystaw, Lublin, Kazimierz, Radom, Zwoleń i dalej do Wielkopolski bądź w kierunku Wrocławia ${ }^{14}$. $\mathrm{Z}$ owym dyplomem koresponduje inne postanowienie królewskie z tego roku, obligujacce kupców krasnostawskich udających się ku Wrocławiowi, Poznaniowi, Toruniowi i Gnieznu do podróżowania przez Lublin (punkt poboru cła). Z kolei podążając do Krakowa i Sandomierza, musieli wędrować przez Wysokie, Kraśnik i Zawichost ${ }^{15}$. Wówczas stopniowo traciła rangę wymiana na linii Bałtyk - Morze Czarne, a zyskiwały kontakty handlowe osi Kraków - Wilno, co było konsekwencją m.in. zawarcia unii polsko-litewskiej w Krewie z 1385 r. ${ }^{16} \mathrm{~W}$ ramach monarchii polsko-litewskiej umocniła się pozycja Lublina, jarmarki lubelskie wyrosły $\mathrm{z}$ czasem na jedne z najznaczniejszych na mapie Polski ${ }^{17}$. Profity z tego czerpał także Krasnystaw, który był znaczącym miastem ziemi chełmskiej

${ }^{12}$ H. Samsonowicz, Przemiany osi drożnych $w$ Polsce późnego średniowiecza, $\mathrm{PH}$, t. 64, 1973, nr 4, s. 702-703; Ł. Charewiczowa, Handel średniowiecznego Lwowa, Lwów 1925 , s. 32,37 .

${ }^{13}$ Ł. Charewiczowa, dz. cyt., s. 34, 37; S. Weymann, Cta i drogi handlowe $w$ Polsce piastowskiej, Poznań 1938, s. 115.

${ }_{14}$ Archiwum Państwowe w Lublinie (dalej: APL), Dokumenty miasta Lublina, rkps 12.

15 ZDM, t. 3: Dokumenty z lat 1442-1450, wyd. S. Kuraś, Wrocław 1969, nr 869, s. $370-371$.

${ }^{16}$ H. Samsonowicz, Przemiany osi drożnych..., s. 704.

${ }_{17}$ K. Myśliński, Lublin a handel Wrocławia z Rusia, „Rocznik Lubelski” 3, 1960, s. 17. W połowie XV w. rozpoczął się prawdziwy renesans handlowy Lublina, do czego walnie przyczynił się przywilej królewski z 1448 r. zwiększający liczbę jarmarków lubelskich do czterech. 
na wspomnianym szlaku komunikacyjnym ze Lwowa do Lublina. Symbolicznym potwierdzeniem jego pozycji było przeniesienie w $1490 \mathrm{r}$. siedziby biskupstwa rzymskokatolickiego z Chełma do Krasnegostawu ${ }^{18}$. W XVI w. pod względem demograficznym Krasnystaw miał status miasta średniej wielkości. W połowie tego stulecia mieszkało w nim ok. 1500 osób, porównywalnie do Tarnogóry, Chełma i Hrubieszowa, a nieco mniej od Ratna, najludniejszego miasta ziemi chełmskiej ${ }^{19}$.

Przy analizie uwarunkowań kondycji miast w okresie wczesnonowożytnym nie można pominąc rodzącego się w tym czasie zjawiska „rewolucji cenowej” w Europie, odznaczającego się ogólnym wzrostem cen, ale przy większej dynamice w przypadku artykułów żywnościowych niż rzemieślniczych czy płac. Z powodu rosnącego popytu na płody rolne, będącego konsekwencją wzrostu liczby ludności, znaczenia nabierał handel śródlądowy. Tylko tą drogą można było najtaniej przewieść towary masowe, jak zboże, które docierało także do zagranicznych kontrahentów. Dostrzegali to polscy władcy, dlatego eliminowano istniejące bariery w handlu rzecznym. Statut piotrkowski z 1447 r. nakazywał, pod groźbą kary 14 grzywien denarów, usunięcie przeszkód wodnych oraz wprowadzał wolna żeglugę na rzekach „Wisła, [D]niepr, Styr, Narew, Warta, Dunajec, Wisłoka, Bug, Bruki [Brok - D.W.], Wieprz, Tyśmienica, San, Nida, Prosna" ${ }^{20}$. W konstytucji 1496 r. dodano jeszcze Noteć, a potem przepisy te przywoływano i poszerzano w kolejnych uchwałach sejmu walnego, np. w 1589 r., kiedy wprost odniesiono się do cieku wodnego biegnacego przez Krasnystaw, zezwalając właścicielom młynów na pozostawienie grobli i jazów, jednakże pod warunkiem zabezpieczenia żeglowności przez „instrumenta, powrozy i inne potrzeby

18 Szerzej na ten temat zob. B. Kumor, Przeniesienie stolicy biskupiej z Chetma do Krasnegostawu (1490), „Archiwa Biblioteki i Muzea Kościelne” 49, 1984, s. 369-380.

${ }_{19}$ Lustracja województw ruskiego, podolskiego $i$ betskiego..., s. 6, 18, 24-25. Szacunkową liczbę mieszkańców uzyskano na podstawie informacji o liczbie domów miejskich i podmiejskich (Krasnystaw - 199 domów), przy zastosowaniu powszechnie przyjmowanego mnożnika 6 osób na dom i orientacyjnym doliczeniu mieszkańców jurydyk szlacheckich i duchownych. Jak wykazali P. Guzowski, R. Poniat, Przeliczniki demograficzne $w$ szacunkach zaludnienia miast $w$ Królestwie Polskim $w$ drugiej połowie XVI wieku, „Przeszłość Demograficzna Polski” 37, 2005, nr 2, s. 90, stosowanie powyższego przelicznika jest zasadne w przypadku miast stosunkowo niewielkich, a takimi były ośrodki ziemi chełmskiej. Por. R. Szczygieł, Hrubieszów w okresie staropolskim. Charakterystyka etapów rozwoju miasta, w: Hrubieszów przez dzieje, Hrubieszów 1990, s. 32; Т.В. Сидорук, Соціально-еконолічний розвиток Ратненського староства у XVI-XVII cm. (1500-1674 рр.), Острог 2007, mps w zbiorach autora, s. $52-54$.

${ }^{20}$ VL, t. 1, Petersburg 1859, s. 69. 
do tego należące naczynie wodne [śluza - D.W.]"21. Doskonale rozumiała to miejscowa szlachta, która szczególna aktywność w tym względzie przejawiała w ostatnim okresie rządów Zygmunta Augusta, uchwalając w latach 1564, 1567 i 1569 podatek na utrzymanie spławności Wieprza (2 gr z łanu i kwartnik czopowego) ${ }^{22}$.

Wisła - jak zaznaczył Jan M. Małecki - stała się najważniejszym szlakiem handlowym Rzeczypospolitej. Z tego też względu zyskały gospodarczo osady położone w dorzeczu tej spławnej arterii komunikacyjnej ${ }^{23}$. Dotyczy to także ziemi chełmskiej i ośrodków znajdujących się w pobliskim sassiedztwie takich rzek, jak Bug i Wieprz. Zlokalizowany przy tym ostatnim Krasnystaw niewątpliwie zyskiwał gospodarczo, a rozchylające się „nożyce cenowe” na korzyść płodów rolnych wzmacniały popyt mieszkańców obszarów wiejskich na miejskie wyroby rzemieślnicze ${ }^{24}$. Miejscy kupcy pośredniczyli w kontaktach handlowych ich zaplecza wiejskiego, zwłaszcza w eksporcie produktów rolnych i leśnych transportowanych Wisłą do Gdańska. Najwięcej wywożono zboża, które następnie wiosna spławiano „mało niżej Krasnego stawu”25, tj. z należącej do starostwa krasnostawskiego wsi Stężyca, do której z miasta prowadził gościniec. Wzrost ilości dostarczanego do Krasnegostawu zboża folwarcznego angażował także starostę sprawującego nadzór nad spławem ${ }^{26}$. Najważniejsza dla XVI w. wiślana komora celna we Włocławku, zachowana dla okresu 1537-1576, ukazuje aktywność kupców krasnostawskich w latach 1573 (18 łasztów), 1574 (32 łasztów) i 1576 (6 łasztów) ${ }^{27}$. $\mathrm{Z}$ ziemi chełmskiej w 1556 r. spławiono 526,5 łasztów zboża, w 1568 r. 356 łasztów, a w 1575 r. $-216^{28}$. W tym ostatnim roku „z dołu” na ten

${ }^{21}$ Volumina Constitutionum, t. 2: 1550-1609, cz. 2: 1587-1609, oprac. S. Grodziski, przedm. W. Uruszczak, Warszawa 2008, s. 111.

${ }_{22}$ Volumina Constitutionum, t. 2: 1550-1609, cz. 1: 1550-1585, oprac. S. Grodziski, I. Dwornicka, W. Uruszczak, Warszawa 2005, s. 147, 210, 262.

${ }_{23}$ J.M. Małecki, Zwiazki handlowe miast polskich $z$ Gdańskiem w XVI i pierwszej połowie XVII wieku, Wrocław 1968, s. 48.

${ }^{24} \mathrm{~W}$ literaturze przedmiotu wskazuje się na $25 \%$ i większy udział mieszczan w handlu wiślanym; zob. S. Hoszowski, Handel Gdańska w okresie XV-XVIII wieku, „Zeszyty Naukowe Wyższej Szkoły Ekonomicznej w Krakowie” 1960, nr 11, s. 19-20; J.M. Małecki, dz. cyt., s. 182.

25 Жерела до історії Украӥни-Руси, t. 3, wyd. М. Грушевський, Lwów 1900, s. 21.

${ }^{26}$ R. Rybarski, Handel i polityka handlowa Polski w XVI stuleciu, t. 1: Rozwój handlu i polityki handlowej, Poznań 1928, s. 40.

${ }^{27}$ J.M. Małecki, dz. cyt., s. 118, 203. Z pewnościa aktywność kupców krasnostawskich była wyższa, gdyż rejestry celne nie odzwierciedlaja pełnej skali procederu.

${ }^{28}$ R. Rybarski, Handel $i$ polityka handlowa Polski $w$ XVI stuleciu, t. 2: Tablice $i$ materiaty statystyczne, Poznań 1929, s. 18. 
obszar spławiono 60 beczek śledzi (1574 r. - 72, 1576 r. - 30) ${ }^{29}$. Kupowali je w Gdańsku kupcy, zarówno szlachta, jak i mieszczanie, wcześniej sprzedawszy tam zboże. Dominujący import szlachecki zasadniczo pokrywał zapotrzebowanie na śledzie panów braci, a dostarczane przez kupców miejskich trafiały na stoły mieszczan i chłopów ${ }^{30}$. Z tej reguły wyłamywali się handlarze żydowscy, np. odnotowany w księdze miejskiej pod rokiem 1604, którego sklep zaopatrywał się w śledzie od podsędka bełskiego Marcina Rogali ${ }^{31}$.

Sasiedztwo ziemi chełmskiej z pobliskim Wołyniem ożywiało wymianę towarowa. Z Wołynia m.in. przez Łuck i Włodzimierz, a następnie Hrubieszów i właśnie Krasnystaw pędzone były woły, które dalej przez Lublin, Kazimierz, Zwolen, Radom i kolejne ośrodki - docierały do zachodniej Polski ${ }^{32}$. Przebieg tej trasy ustanowił już w 1493 r. król Jan Olbracht ${ }^{33}$. Wcześniej, bo od czasów Kazimierza Jagiellończyka za jednorazowy przejazd mostami na komorze celnej w Krasnymstawie pobierano myto mostowe. Otrzymany z tego tytułu dochód od 1524 r., za pozwoleniem królewskim, zasilał kasę miasta. Mostowe uiszczano od każdej sztuki bydła w wysokości 1 ternara (równowartość 3 denarów) ${ }^{34}$. Od 1558 r. (z potwierdzeniem w 1578 r.) na mocy przywileju Zygmunta Augusta opłatę rozszerzono na każdego konia zaprzęgniętego do wozu (1 szelag) oraz przewożone na nim towary (6 denarów) ${ }^{35}$. Mostowe obowiązywało jedynie kupców obcych, gdyż mieszczanie krasnostawscy byli zwolnieni od ceł i myt, dzięki przywilejowi królewskiemu $\mathrm{z} 1552$, potwierdzonemu w $1591 \mathrm{r}^{36}$

Od XVI w. ważny szlak handlu wołami prowadził na Ślask z Kamieńca Podolskiego m.in. przez Busk, Bełz, Tyszowce, Zamość, Krasnystaw, Lublin, Kazimierz, Radom i Wieluńn ${ }^{37}$. Zamość rychło stał się istotnym

29 Tamże, s. 20.

${ }^{30}$ W.H. Berkowski, Wotyńsko-gdańskie kontakty handlowe $w$ XVI-pierwszej połowie XVII wieku, „Acta Historica Universitatis Klaipedensis” 14, 2007, s. 51.

${ }_{31}$ APL, Akta miasta Krasnegostawu (dalej: AmKr), sygn. 2, k. 33.

32 S. Weymann, Ze studiów nad zagadnieniem dróg $w$ Wielkopolsce od X do XVIII w., „Przegląd Zachodni” 1953, nr 6-8, s. 223.

${ }^{33}$ P. Jusiak, Krasnystaw na szlakach handlowych w średniowieczu, „Zapiski Krasnostawskie" 4, 2013, s. 29.

${ }^{34}$ AGAD, Metryka Koronna (dalej: MK), t. 36, s. 668-670; AGAD, Komisja Rządowa Spraw Wewnętrznych (dalej: KRSW), sygn. 3194, s. 23.

${ }^{35}$ Lietuvos mokslų akademijos Vrublevskiu biblioteka (dalej: LMAVB), Dział rękopisów, f. 1-400; AGAD, MK, t. 90, k. 410v-411v.

${ }^{36}$ AGAD, MK, dz. XVIII, t. 47, k. 2; AGAD, KRSW, sygn. 3194, s. 25. Mieszczanie byli zobligowani do wpłacania pieniędzy do skrzynki miejskiej na utrzymanie murów i wałów miejskich.

${ }^{37}$ J. Baszanowski, Handel wołami w Polsce $w$ XVI-XVIII w., Szczęsne 2017, s. 112. 
punktem tranzytowym w handlu wołami pędzonymi z Podola. Z pewnościa lokacja tego miasta w $1580 \mathrm{r}$. stworzyła poważna konkurencję dla oddalonego o zaledwie $30 \mathrm{~km}$ Krasnegostawu. Wraz z powstaniem Zamościa znaczenia nabrał najkrótszy szlak prowadzacy ze Lwowa do Lublina. Biegł m.in. przez Rawę, późniejszy Tomaszów, Zamość i Krasnystaw. Jeszcze w XV w. nie odgrywał większej roli ${ }^{38}$.

Już w XV w. kupcy krasnostawscy udawali się ze skórami do Gniezna, Poznania, Torunia i Wrocławia ${ }^{39}$. Docierali także do Lwowa, Jarosławia, utrzymywali również kontakty z kupcami m.in. z Wilna i Brześcia. Najczęściej jednak brali udział w pobliskich jarmarkach lubelskich ${ }^{40}$. Analizowany przez Romana Rybarskiego rejestr komory wieluńskiej z lat 1534/1535 notuje 1100 sztuk wielkich skór wołowych (na ogólną liczbę 27 336) wiezionych przez kupców z Krasnegostawu ${ }^{41}$. Skóry najczęściej pochodziły z uboju bydła pędzonego z Wołynia lub Podola, w którego eksporcie uczestniczyli handlarze $\mathrm{z}$ Krasnegostawu ${ }^{42}$. Byli wśród nich m.in. bogaci kupcy ruscy - bracia Iwan i Olechno Borzobohaci, którzy w 1545 r. zakupili na kredyt u hospodara mołdawskiego Piotra Raresza 1000 wołów za kwotę 3 tys. złp. Kupcy z Krasnegostawu nie kwapili się $\mathrm{z}$ uiszczeniem zapłaty ${ }^{43}$. W $1646 \mathrm{r}$. podobną nierzetelnością wykazała się mieszczka krasnostawska Dorota Kroczowska, która na wszelkie sposoby ociagała się z zapłaceniem 300 złp za dostarczone wino węgierskie od kupca z Jaślik Stefana Almazego ${ }^{44}$.

Istotną rolę w życiu gospodarczym miasta odgrywali kupcy handlujący solą którą przywożono z żup drohobyckich. Rozwój tej gałęzi handlu nie byłby możliwy bez stosownego wsparcia królewskiego. W 1518 r. Zygmunt I Stary udzielił miastu Krasnystaw przywileju na wybudowanie składu na sól i woskobojni, czyli warsztatu do wyciskania wosku.

38 A. Szykuła, J. Żygawski, Szlak Lwów-Lublin. Geneza, zmiany przebiegu i funkcje do końca XIX wieku, w: Ziemiaństwo na Lubelszczyźnie IV. Ziemianie w podróży. Materiaty IV sesji naukowej zorganizowanej w Muzeum Zamoyskich w Kozłówce $w$ dniach 8-10 października 2008 roku, t. 1, red. H. Łaszkiewicz, Lublin 2010, s. 374.

${ }^{39}$ B. Zimmer, Miasta ziemi chetmskiej od XIII do pot. XIX w. w zarysie, Lublin 1993, s. 65.

${ }^{40}$ R. Szczygieł, Powstanie miasta Krasnegostawu i jego dzieje w XV wieku, „Zapiski Krasnostawskie” 5, 2014, s. 19.

${ }^{41}$ R. Rybarski, Handel i polityka handlowa..., t. 2, s. 162-163.

${ }^{42}$ J. Baszanowski, dz. cyt., s. 172.

${ }^{43}$ Źródta dziejowe, t. 10: Sprawy wołoskie za Jagiellonów. Akta i listy, wyd. A. Jabłonowski, Warszawa 1878, s. CXXVIII, 135-136. Z uwagi na zwłokę w zapłacie hospodar mołdawski interweniował m.in. u kasztelana chełmskiego i starosty krasnostawskiego oraz samego króla Zygmunta Augusta.

${ }_{44}$ APL, AmKr, sygn. 44, k. 1-11v. Pomimo wyroków ławy miejskiej nakazujących zapłatę, do 1648 r. mieszczka krasnostawska uiściła niewielką część zobowiązań. 
Handlujący solą zobowiązani byli uiszczać do skrzynki miejskiej opłatę w wysokości 1 gr od wozu i 9 denarów od beczki soli. Dochód z woskobojni władze miejskie zobligowane były przeznaczać na rewitalizację murów. Dzięki zrealizowaniu inwestycji kolejny dyplom królewski z 1525 r. ustanawiał w mieście skład soli ${ }^{45}$. Lustratorzy zarówno w 1569, jak i 1616 r. odnotowali, że prasołowie sprzedali 500 tołp soli, płacąc 5-złotowy zryczałtowany czynsz do skarbu starościńskiego ${ }^{46}$. Koresponduje to z informacjami z rejestrów poborowych o 17 sprzedawcach soli (w 1589 i 1591 r.), którzy stanowili ponad połowę (53\%) wszystkich kupców i kramarzy, obliczanych przez poborcę na $32^{47}$. Miasto nie było jednak dużym ośrodkiem handlu solnego, co potwierdza chociażby regestr komory drohobyckiej za lata 1549-1550: w Krasnymstawie dostarczono 202 mili soli, a dla porównania: w Lubomlu - 2364, a w Chełmie $-3484^{48}$. Część kupców - jak już po trosze omówiono - parała się skupem, sprzedażą oraz organizacją transportu zboża, popiołu i bydła, a także sprzedażą ryb, chmielu i wosku ${ }^{49}$. Nie sposób pominać aptekarza, wytwarzającego i sprzedającego lekarstwa oraz przyprawy, wymienionego w obydwu przywoływanych wyżej rejestrach - z 1589 i $1591 \mathrm{r} .{ }^{50}$ Dla porównania rejestr poborowy z $1563 \mathrm{r}$. notuje 15 kramarzy i 15 kupców, w tym 5 obwoźnych handlarzy ${ }^{51}$. Oznacza to, że w drugiej połowie XVI w. handel krasnostawski nie przeżywał jakiśs zasadniczych trudności, raczej można mówić o jego stabilizacji.

\section{Rzemiosło}

W strukturze zawodowej ludności miast królewskich znaczną rolę odgrywało rzemiosło, otaczane opieką ze strony władców. Najsilniejsze branże organizowały się w samodzielne cechy. Już w 1448 r. miejscowy wójt wydał przywilej dla szewców, zezwalając im - za opłata $12 \mathrm{gr}$ - na produkcję i sprzedaż wyrobów rzemieślniczych w 24 jatkach ${ }^{52}$. To właśnie cech szewski zaczął działać najwcześniej. W drugiej połowie XV w. funkcjonował też cech kuśnierski, którego statut zatwierdził

${ }^{45}$ AGAD, MK, t. 36, s. 671-672; AGAD, MK, t. 63, k. 222-225.

46 Жерела..., t. 7, s. 2; AGAD, MK, dz. XVIII, t. 47, k. 5.

${ }^{47}$ AGAD, ASK, dz. I, sygn. 37, k. 924v, 986v. Rejestr łanowego z 1589 r. podaje także 3 przekupki.

${ }^{48}$ R. Rybarski, Handel i polityka handlowa..., t. 2, s. 250.

${ }^{49}$ BKUL, sygn. 2362, s. 84.

${ }^{50}$ AGAD, ASK, dz. I, sygn. 37, k. 924, 986.

${ }^{51}$ Tamże, k. 612.

${ }^{52}$ ZDM, t. 8: Dokumenty z lat 1435-1450, wyd. I. Sułkowska-Kuraś, S. Kuraś, Wrocław 1975, nr 2517, s. 326-327. 
król Kazimierz Jagiellończyk w 1487 r., a Zygmunt August potwierdził w 1558 r. Kuśnierze uzyskali przywilej wywożenia swoich wyrobów przez Kazimierz ${ }^{53}$. Kolejni władcy wydawali i potwierdzali przywileje cechowe: szewców (1558), rzeźników (1558) i krawców (1562). Z uwagi na mniejszą liczebność majstrów z innych profesji powstawały także cechy zbiorowe, zrzeszające rzemieślników wytwórczości drzewnej: bednarzy, stelmachów, stolarzy i dodatkowo czapników z branży włókienniczej (1558). Osiem lat później powstały cechy grupujące majstrów z gałęzi metalowej: kowali, mieczników, ślusarzy i złotników oraz skórzanej: rymarzy i siodlarzy. W 1637 r. król Władysław IV zatwierdził statut powstałego w tym roku cechu tkackiego ${ }^{54}$. Z tegoż roku pochodzi także wyjątkowy dokument - akt nadania serwitoratu utalentowanemu chirurgowi z Krasnegostawu Andrzejowi Schroderowi, który z sukcesami leczył dostojników dworu królewskiego. Odtąd w całej Polsce mógł swobodnie realizować praktykę lekarską. Poza tym nie musiał uiszczać podatków miejskich i podlegał wyłącznie sądowi marszałka dworu ${ }^{55}$.

Zrzeszenia rzemieślnicze broniły monopolu produkcji, czego dobitnym przykładem był zapis w statucie cechu szewskiego z 1608 r., aby „partaczowi nie wolno być ani pod zamkiem ani na gruncie księżym, ani na przedmieściu i we wsi za mile od miasta" ${ }^{6}$. Ponadto rzymskokatoliccy majstrowie starali się blokować prawosławnym Rusinom dostęp do cechów i możliwość parania się rzemiosłem. Król Zygmunt Stary w 1523 r. zakazał tych praktyk i zrównał pod względem prawnym chrześcijan obrządków katolickiego i prawosławnego (potwierdzenie w 1589 r. $)^{57}$. Z drugiej jednak strony obostrzenia obowiązywały także Żydów krasnostawskich. Wydany dla miasta w 1554 r. przywilej królewski de non tolerandis Judaeis, potwierdzony przez Stefana Batorego w 1578 r., zabraniał starozakonnym posiadania domów w mieście. Mogli osiedlać się jedynie na przedmieściach ${ }^{58}$.

Z 1564 r. dysponujemy źródłami skarbowymi w postaci rejestru poborowego i lustracji, które się wzajemnie uzupełniają. Rejestr szosu

${ }^{53}$ AGAD, MK, t. 91, s. 301v-306.

${ }^{54}$ Wojewódzka Biblioteka Publiczna im. H. Łopacińskiego w Lublinie, sygn. 376, s. 1-2; AGAD, KRSW, sygn. 3194, s. 25, 29; MRPS, cz. 5, t. 1, nr 2247, s. 135-136; AGAD, MK, t. 90, k. 406-407v.

${ }^{55}$ AGAD, MK, t. 181, s. 215v-216.

${ }^{56}$ Wojewódzka Biblioteka Publiczna im. H. Łopacińskiego w Lublinie, sygn. 376, s. 9.

57 Описание Рукописного отделения Виленской публичной библиотеки, t. 4, Вильна 1903, s. 18-20. To rozstrzygnięcie prawne nie zapobiegło rywalizacji ekonomicznej prawosławnych i katolików.

${ }^{58}$ AGAD, MK, t. 86, s. $157 \mathrm{v}-158$. 
wymienia - nieodnotowaną w lustracji - sumaryczna liczbę opodatkowanych rzemieślników: 151 majstrów oraz 3 czeladników ${ }^{59}$. Z kolei lustracja wzmiankuje m.in. o piekarzach, podając wysokość zapłaconego podatku na poziomie 3 złp $20 \mathrm{gr}^{60}$. Dla porównania lustracja z 1569 r. odnotowuje wyższy podatek od piekarzy - 5 złp $10 \mathrm{gr}^{61}$. Identyczny wymiar czynszu zawiera inwentarz z 1572 r., który dodatkowo uwzględnia liczebność tego rzemiosła - „20 piekarek”62. Przyjmując wartość 2-groszowego podatku od piekarzy za każdy kwartał, wnoszonego w „suche dni” [kwartalnie dni postu, tj. środa, piatek, sobota - D.W.], można przyjaćc, że także w 1569 r. działało 20 piekarzy. W 1564 r. sytuacja była bardziej skomplikowana, gdyż wykazany czynsz 3 złp 20 gr $^{63}$, przy zastosowaniu przelicznika 8-groszowego na rok, nie daje liczby całkowitej. Kwestię wyjaśnia informacja $\mathrm{z}$ alternatywnej wersji lustracji z tego roku, w której podano 14 piekarzy, informujacc, że 13 z nich zapłaciło za rok czynsz 8-groszowy, a jeden tylko $6 \mathrm{gr}^{64}$.

Znacząca pozycję wśród rzemieślników krasnostawskich zajmowali szewcy i rzeźnicy. Dysponowali wybudowanymi w rynku jatkami, co poświadcza ich dużą rolę w mieście. Wiemy, że jatek szewskich było 24 , a rzeźniczych 16 . Zostały wybudowane przez wójta i oddane w wieczystą dzierżawę, a po wykupieniu wójtostwa przez króla w pierwszej

59 AGAD, ASK, dz. I, sygn. 37, k. 780; por. Źródta dziejowe, t. 18, cz. 1: Polska XVI wieku pod względem geograficzno-statystycznym, t. 7, cz. 1: Ziemie ruskie. Ruś Czerwona, wyd. A. Jabłonowski, Warszawa 1902, s. 192. Wydany drukiem rejestr poborowy pomija wartość podatku kotłów gorzałczanych. K. Boroda podważył wiarygodność edycji rejestrów w Źródtach dziejowych, wskazując na ich błędy, sięgające nawet $70 \%$ wpisów; zob. tenże, O przydatności rejestrów poborowych $z$ XVI wieku w badaniach demograficznych, „Przeszłość Demograficzna Polski” 33, 2014, s. 37. Należy dodać, że o rok wcześniejszy rejestr szosu ukazuje niższy potencjał rzemiosła miejskiego (134 majstrów), co zapewne było konsekwencja mniej precyzyjnej rejestracji skarbowej; por. AGAD, ASK, dz. I, sygn. 37, k. 612.

${ }^{60}$ Lustracja województw ruskiego, podolskiego i bełskiego..., s. 6. Opłata dzierżawna na rzecz starosty z łaźni miejskiej wynosiła rocznie 17 złp 18 gr (identycznie w latach 1569 i 1572). W lustracjach z 1616 i 1661 r. nie odnotowano tej pozycji podatkowej, co oznacza, że najprawdopodobniej łaźnia spaliła się podczas któregoś z wielu pożarów. Być może jednak przeszła pod zarząd miasta, dlatego czynsz z tytułu dzierżawy przestał być przedmiotem zainteresowania lustratorów, którzy identyfikowali tylko pozycje podatkowe na rzecz starosty.

61 Жерела..., t. 7, s. 2.

${ }^{62}$ AGAD, ASK, dz. LVI, sygn. 105, k. 64v.

${ }^{63}$ Lustracja województw ruskiego, podolskiego i betskiego..., s. 6. Sami lustratorzy potwierdzali, że liczba piekarek ulegała zmianom, „przeto co się ich opowie na kwartał, tyle ich rejestruja".

${ }_{64}$ Жерела..., t. 3, s. 5-6. Wydanie tej lustracji podaje wiele interesujacych uzupełnień w stosunku do edycji warszawskiej. 
połowie XVI w. pobierany z nich coroczny czynsz trafiał do starosty ${ }^{65}$. Ilość odnotowanych w lustracjach jatek rzeźniczych i szewskich wyznaczała maksymalną w tych branżach liczbę majstrów, która podlegała wahaniom, dlatego nie zawsze wszystkie jatki były wykorzystywane. W 1564 i 1569 r. rejestrujemy 16 rzeźników z identyczną wartościa jednostkowej opłaty (24 gr) i sumy zapłaconego podatku (12 złp $24 \mathrm{gr})^{66}$. W inwentarzu z 1572 r. sumaryczna kwota czynszu nie zmienia się, ale mamy adnotację już tylko o 8 rzeźnikach, dla których zastosowano wyższa taryfę (po $1 \mathrm{złp} 18$ gr) ${ }^{67}$. Podczas targów magistrat zezwalał na sprzedaż mięsa także rzeźnikom pozacechowym (tzw. sochaczom), również spoza miasta. $Z$ tytułu sprzedaży mięsa pobierano na rzecz starosty daninę $\mathrm{w}$ naturze $\mathrm{w}$ postaci sztuki mięsa wartej - $\mathrm{w}$ zależności od wielkości sprzedanego bydła - grosz lub półgroszy ${ }^{68}$.

Przyjmując wykorzystywaną wyżej metodę szacowania, możemy ustalić liczbę 24 szewców w 1569 r., choć lustratorzy zastrzegli, że taryfa 12 gr „różnie przychodzi, jednego roku mniej, drugiego więcej” ${ }^{69}$. Z kolei lustracja z 1564 r. nieprecyzyjnie podaje, że z 24 jatek „natenczas pustych niemało"70. Gdy jednak zestawimy identyczną wartość zapłaconego podatku od jatek szewskich z lustracji z 1564 r. i czynszu od szewców z inwentarza z 1572 r. (7 złp 12 gr) oraz uwzględnimy informację o jednostkowej niezmiennej opłacie czynszowej 12 gr i wzmiankę w przywoływanym inwentarzu, że z 24 szewców „teraz nie masz jedno 18”71, należy wnioskować, że podobnie jak w 1572, także w 1564 r. funkcjonowało w mieście 18 szewców.

$\mathrm{Z}$ przytoczonych danych wyłania się obraz bardzo dużej roli rzemiosła krasnostawskiego w życiu gospodarczym miasta. Porównując wspomnianą już wcześniej liczbę 151 majstrów z rejestru poborowego z 1564 r. (czy nawet 134 z rejestru z 1563 r.) z informacją z lustracji z tego czasu o istnieniu 144 domów intra muros (z których 7 było niezamieszkałych) $)^{72}$, możemy skonstatować, że Krasnystaw był miastem

\footnotetext{
${ }^{65}$ BKUL, sygn. 2362, s. 69, 78-79.

${ }^{66}$ Lustracja województw ruskiego, podolskiego i betskiego..., s. 6; Жерела..., t. 7, s. 2.

${ }^{67}$ AGAD, ASK, dz. LVI, sygn. 105, k. 64v.

${ }_{68}$ Lustracja województw ruskiego, podolskiego i betskiego..., s. 6; Жерела..., t. 3, s. 6.

69 Жерела..., t. 7, s. 2. Z uwagi na niepełny pobór czynszu od szewców zapłacili oni 18 gr mniej (9 złp).

${ }^{70}$ Lustracja województw ruskiego, podolskiego $i$ betskiego..., s. 6.

71 Tamże; AGAD, ASK, dz. LVI, sygn. 105, k. 64v.

${ }^{72}$ Lustracja województw ruskiego, podolskiego $i$ betskiego..., s. 5. Liczba domów na przedmieściach wynosiła 55. Inwentarz z $1544 \mathrm{r}$. określa liczbę domów w mieście na 143, na przedmieściach zaś na 48; zob. AGAD, ASK, dz. LVI, sygn. 105, k. 3.
} 
rozwiniętego rzemiosła. Zgodnie z klasyfikacja przyjęta przez Marię Bogucką należy go zaliczyć do większych skupisk rzemieślniczych, gdyż z powodzeniem spełnia zaproponowane kryterium produkcji w 100-200 warsztatach obsługiwanych przez 40-50\% mieszkańców ${ }^{73}$. Trudno jednoznacznie stwierdzić, czy w każdym domu znajdował się warsztat rzemieślniczy, czasami bowiem w jednym ręku łączono dwa pokrewne rzemiosła. Nawet niekiedy karczmarze dodatkowo parali się piekarstwem i rzeźnictwem ${ }^{74}$. Można jednak przypuszczać, że w połowie XVI w. rzemieślnicy stanowili nawet ponad 90\% populacji Krasnegostawu (bez przedmieść). Duży potencjał miejscowego rzemiosła to składowa kilku przesłanek: zasobnego rynku lokalnego, pełnienia przez miasto funkcji węzła komunikacyjnego na ważnym trakcie handlowym oraz zadań sądowo-administracyjnych (siedziba starostwa i biskupstwa). Kupcy i rzemieślnicy obsługiwali przede wszystkim rynek lokalny, a wymiana handlowa $\mathrm{z}$ innymi miastami miała znaczenie uzupełniające. Istotna funkcją handlowa Krasnegostawu była obsługa tranzytu. Implikowała, jak zauważa Andrzej Wyrobisz, występowanie znacznej liczby rzemieślników nastawionych na obsługę podróżujących: w branży spożywczej piekarzy, rzeźników i piwowarów, a w metalowej kowali, kołodziejów i stelmachów ${ }^{75}$. Źródła skarbowe dowodza, że właśnie te zawody były w Krasnymstawie szczególnie częste. Oczywiście wszystkie wymienione branże wiążą się także, zwłaszcza piekarstwo, rzeźnictwo i kowalstwo, z zaspokajaniem potrzeb samego miasta i najbliższej okolicy.

Ze źródeł skarbowych wyłania się dość niepokojący obraz pogarszania się kondycji rzemiosła w Krasnymstawie od lat siedemdziesiątych XVI stulecia. Już rejestr poborowy z 1570 r. odnotowuje podatek od tylko 90 rzemieślników i 14 czeladników ${ }^{76}$. Jeśli przyjąć, że poborca wykazał się dostateczną rzetelnościa, to tak gwałtowny spadek liczby opodatkowanych majstrów (o $61 \mathrm{w}$ stosunku do $1564 \mathrm{r}$.) można próbować wyjaśnić największą w tym stuleciu klęską głodu, która dotknęła Rzeczpospolitą w latach 1570-1573. Towarzyszyła temu

${ }^{73}$ M. Bogucka, H. Samsonowicz, Dzieje miast i mieszczaństwa $w$ Polsce przedrozbiorowej, Wrocław 1986, s. 429.

${ }^{74}$ B. Baranowski, Polska karczma, restauracja, kawiarnia, Wrocław 1979, s. 10.

75 A. Wyrobisz, Typy funkcjonalne miast polskich $w$ XVI-XVIII $w$., PH, t. 72, 1981, nr 1 , s. 37.

${ }^{76}$ AGAD, ASK, dz. I, sygn. 37, s. 882v. Rejestr poborowy z 1570 r. wylicza 90 majstrów bez wskazania profesji oraz 15 rybaków, a także 15 kramarzy. Biorąc pod uwagę retrogresywną informację z 1563 r. o 30 osobach trudniących się handlem (por. tamże, k. 612), można szacować liczbę prasołów na 15 osób. Na zasadzie analogii podobne proporcje należy przyjąć dla $1563 \mathrm{r}$. 
epidemia $^{77}$. W 1575 r. krasnostawscy rzemieślnicy musieli się zmierzyć z kolejnym zagrożeniem w postaci wielkiego pożaru, który strawił znaczną część zabudowy miejskiej i podmiejskiej ${ }^{78}$. Zapewne stało się tak wskutek świadomego podpalenia przez Tatarów, którzy złupili wówczas miasto $^{79}$. Nie bez powodu w 1578 r. mieszkańcy nie uiścili czopowego i szosu ${ }^{80}$, a rejestry poborowe z 1589 i 1591 r. notuja niemal dwukrotne zmniejszenie się liczby majstrów (do $83 \mathrm{w} 1591 \mathrm{r}$. w mieście i 1 na przedmieściach) $\mathrm{w}$ stosunku do lat sześćdziesiątych tego wieku. Z kolei radykalnie wzrosła liczba czeladników (do 21 w 1589 r.), a gdy w 1591 r. zanotowano ich 13 , to ten ubytek nie przełożył się na ilościowy wzrost majstrów posiadających warsztaty rzemieślnicze ${ }^{81}$. To najpewniej konsekwencja obserwowanego w tym czasie w Koronie zjawiska zamykania się cechów ${ }^{82}$. Być może wyzwoleni czeladnicy skorzystali z atrakcyjnej oferty dynamicznie rozwijajacego się nowo lokowanego Zamościa. Warto podkreślić znaczenie rejestrów poborowych z 1589 i 1591 r., uwzględniających strukturę zawodową rzemiosła krasnostawskiego ${ }^{83}$ (zob. tab. 1).

Z rzemiosł o charakterze usługowym widzimy aptekarza i łaziebnika, który obsługiwał łaźnię miejska. Licznie reprezentowane były branże skórzana i włókiennicza, a szczególnie rolno-spożywcza. Oprócz 18 piekarzy

77 A. Karpiński, W walce z niewidzialnym wrogiem. Epidemie chorób zakaźnych $w$ Rzeczypospolitej XVI-XVIII wieku i ich nastepstwa demograficzne, społeczno-ekonomiczne i polityczne, Warszawa 2000, s. 25; J. Majer, Obraz postepu nauki lekarskiej, o ile nań wptynęty pisma polskie, lub przez Polaków w trzech ostatnich latach wydane, Kraków 1840 (odb.: „Rocznik Wydziału Lekarskiego w Uniwersytecie Jagiellońskim” 3), s. 407.

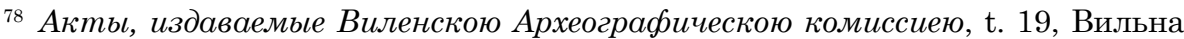
1892, s. 176; zob. BKUL, sygn. 2362, s. 74. L. Bieńkowski na podstawie analizy księgi miejskiej z lat 1586-1590, w której nie występują informacje o pustych placach, uznał, że tkanka mieszkalna została dość szybko odbudowana.

79 J. Ternes, dz. cyt., s. 34.

80 Źródta dziejowe, t. 9, cz. 2: Księgi podskarbińskie z czasów Stefana Batorego 1576-1586, wyd. A. Pawiński, Warszawa 1881, s. 277; Центральний державний історичний архів України, м. Київ, f. 1, ор. 1, nr 2, k. 266.

${ }^{81}$ AGAD, ASK, dz. I, sygn. 37, k. 924-924v, 986-986v.

82 A. Mączak, H. Samsonowicz, B. Zientara, Z dziejów rzemiosła $w$ Polsce, Warszawa 1954, s. 47.

${ }^{83}$ BKUL, sygn. 2362, s. 78-81. L. Bieńkowski przypuszcza, że rejestr poborowy z 1589 r. nie identyfikuje wszystkich rzemieślników, sugerując korektę in plus o 88\% dla 6 zawodów. Nie uwzględnił jednak, że w warunkach klęsk elementarnych w księdze miejskiej notowano także tych rzemieślników, którzy utracili swoje warsztaty, przez co nie byli zobowiązani i zdolni do wnoszenia opłat. Z drugiej strony rejestry poborowe z pewnością nie oddają kompletnego obrazu aktywności gospodarczej krasnostawskich wytwórców. 
Tabela 1. Struktura zawodowa i liczebność rzemiosła krasnostawskiego w latach $1589-1591^{84}$

\begin{tabular}{|c|c|c|c|c|c|c|c|c|c|c|c|}
\hline \multicolumn{12}{|c|}{ Branża } \\
\hline \multicolumn{2}{|c|}{ rolno-spożywcza } & \multicolumn{2}{|c|}{ skórzana } & \multicolumn{2}{|c|}{ włókiennicza } & \multicolumn{2}{|c|}{ drzewna } & \multicolumn{2}{|c|}{ metalowa } & \multicolumn{2}{|c|}{ usługowa } \\
\hline \multirow[t]{3}{*}{ piekarz } & \multirow[t]{3}{*}{18} & \multirow[t]{3}{*}{ szewc } & \multirow[t]{3}{*}{12} & tkacz & 7 & \multirow[t]{2}{*}{ stelmach } & \multirow[t]{2}{*}{4} & \multirow[t]{2}{*}{ kowal } & \multirow[t]{2}{*}{6} & & \\
\hline & & & & krawiec & 5 & & & & & & \\
\hline & & & & greeplarz & 4 & \multirow[t]{3}{*}{ bednarz } & \multirow[t]{3}{*}{4} & \multirow{3}{*}{\begin{tabular}{|l|} 
ślusarz \\
kotlarz
\end{tabular}} & & aptekarz & 1 \\
\hline \multirow[t]{2}{*}{ rzeźnik } & \multirow[t]{2}{*}{8} & \multirow[t]{2}{*}{ kuśnierz } & \multirow[t]{2}{*}{3} & czapnik & 2 & & & & \multirow{2}{*}{$\begin{array}{l}3 \\
2\end{array}$} & łaziebnik & 1 \\
\hline & & & & \begin{tabular}{|l|} 
postrzygacz \\
sukna
\end{tabular} & 1 & & & & & & \\
\hline \multirow[t]{2}{*}{ słodownik } & \multirow[t]{2}{*}{2} & \multirow[t]{2}{*}{ rymarz } & \multirow[t]{2}{*}{2} & \multirow[t]{2}{*}{ powroźnik } & \multirow[t]{2}{*}{1} & \multirow[t]{2}{*}{ kołodziej } & \multirow[t]{2}{*}{2} & płatnerz & 2 & & \\
\hline & & & & & & & & złotnik & 1 & & \\
\hline ogółem & 28 & ogółem & 17 & ogółem & 20 & ogółem & 10 & ogółem & 14 & ogółem & 2 \\
\hline
\end{tabular}

Źródło: AGAD, ASK, dz. I, sygn. 37, k. 924-924v, 986-986v.

w mieście i jednego na przedmieściach mamy sporo rzeźników (8 majstrów) oraz 2 słodowników, którzy byli pracownikami najemnymi słodowni bądź ich właścicielami ${ }^{85}$. W tym miejscu należy wspomnieć o rozwoju krasnostawskiego gorzelnictwa, rejestr poborowy z $1591 \mathrm{r}$. wymienia bowiem 2 kotły z wódka (caldearibus cremati) ${ }^{86}$. W Krasnymstawie już wcześniej, co ukazują rejestry poborowe z lat sześćdziesiątych, produkowano w 2 kotłach gorzałkę „prosta” (łac. vinum crematum) ${ }^{87}$. Scott Simpson ustalił, że taki trunek mógł być wytwarzany zarówno z owoców, jak i ze zboża ${ }^{88}$. Niestety, nie zachowały się rejestry czopowego po 1578 r., kiedy zostało ono rozszerzone na wódkę. Wcześniej obejmowało piwo, miód i wino. Ostatni zachowany szczegółowy rejestr czopowego pochodzi z 1567 r. Podatek ten, każdorazowo uchwalany przez sejm - w odróżnieniu od w miarę stabilnych wartościowo corocznych danin na rzecz magistratu i starosty - był świadczeniem niestałym i o zmiennej wysokości. W 1563 r. zapłacono 131 złp 25 gr i 9 denarów,

${ }^{84} \mathrm{Z} 2$ rejestrów poborowych wzięto pod uwagę wyższe wskaźniki liczbowe z wyłączeniem przedmieść.

${ }^{85}$ AGAD, ASK, dz. I, sygn. 37, k. 924-924v, 986-986v. Łaźnię dzierżawiono od starosty. Duchowieństwo krasnostawskie dysponowało własną łaźnią przy katedrze; BKUL, sygn. 2362, s. 105.

${ }^{86}$ AGAD, ASK, dz. I, sygn. 37, k. 924v, 986v. Rejestr poborowy z 1589 r. wymienia 4 opodatkowane kotły, lecz nie uwzględnia ich specyfikacji.

87 Tamże, k. 612, 780.

88 S. Simpson, History and Mythology of Polish Vodka: 1270-2007, „Food \& History” 8, 2010, nr 1, s. 132. 
i była to najwyższa kwota poboru w całej ziemi chełmskiej. W 1565 r. wartość podatku czopowego wyniosła 91 złp 11 gr i 15 denarów, więcej zapłaciły Chełm (190 złp) i Szczebrzeszyn (150 złp); w 1567 r. Krasnystaw uiścił 113 złp 19 gr i 6 denarów, mniej jedynie od Szczebrzeszyna (193 złp 6 gr) ${ }^{89}$. Cenionym napojem alkoholowym był miód pitny, którego w 1563 r. wyprodukowano 236 beczek (najwięcej ze wszystkich miast ziemi chełmskiej), i to w trzech rodzajach: „Krasnostawek”, „Śledziówek” i „Sosnówek”. Podobnej sytuacji nie spotykamy w żadnym innym mieście ziemi chełmskiej, co świadczy o wyjątkowych umiejętnościach krasnostawskich producentów miodów. Mniejsze znaczenie miało tutejsze browarnictwo, według rejestru czopowego z $1563 \mathrm{r}$. wyprodukowano 262,5 warów piwa, a dla porównania Szczebrzeszyn 681, Turobin zaś $-418^{91}$. Wartość podatku od piwa na poziomie $1135 \mathrm{gr}$ i 9 denarów plasuje Krasnystaw w kategorii najmniejszych miejskich ośrodków browarnictwa ${ }^{92}$. Według moich obliczeń całkowita produkcja piwa pełnego w przywoływanym $1563 \mathrm{r}$. wyniosła ponad 290 tys. litrów ${ }^{93}$. Z zachowanych źródeł dowiadujemy się, że już w 1527 r. mieszczanie krasnostawscy uzyskali pozwolenie królewskie (potwierdzone w 1596 r.) na swobodna produkcje gorzałki (vinum sublimatum seu crematum) z przeznaczeniem podatku na potrzeby miasta ${ }^{94}$. Oznaczało to, że oprócz zawodowych piwowarów i gorzelników alkohol mogli wyrabiać także karczmarze. W 1611 r. sytuacja się nieco zmieniła, dzięki przywilejowi królewskiemu mieszczanie i przedmieszczanie mogli bowiem produkować i sprzedawać gorzałkę tylko za zgodą magistratu. Ponadto dochód

${ }^{89}$ AGAD, ASK, dz. I, sygn. 37, k. 727, 822, 833v, 838v, 869, 873. Zgodnie z zaproponowana przez A. Janeczka 5-stopniową klasyfikacją wysokości czopowego dla miast Rusi Czerwonej, Krasnystaw należy zaliczyć do kategorii III, tj. miast średnich (powyżej 1800 gr). Jeżeli weźmiemy pod uwagę wyłącznie rejestr z 1563 r. Krasnystaw plasuje się nawet w kategorii II, tj. ośrodków większych o znaczeniu regionalnym (powyżej 3600 gr); zob. tenże, Miasta prywatne na Rusi Koronnej do końca XV wieku, RDSG, t. 77,2016 , s. 165 .

${ }^{90}$ AGAD, ASK, dz. I, sygn. 37, k. 727. Rejestr czopowego z 1565 r. wykazał 185 beczek miodu oraz 3 duże beczki wina, natomiast z 1551 r. - 266,5 beczek miodu oraz mała i dużą beczkę wina; por. tamże, k. 667-674v, 833v.

${ }_{91}$ Tamże, k. 727, 732-733. W 1565 r. wyprodukowano 179,5, w 1551 r. zaś 162 warów piwa; zob. tamże, k. 658-666, 833v.

${ }_{92}$ Zob. K. Boroda, Geografia gospodarcza..., s. 522. Autor ten na podstawie kwoty czopowego od piwa podzielił miasta na 8 grup, z których najniższa obejmuje ośrodki płacace do 2 tys. gr i produkujace do 300 tys. 1 piwa pełnego rocznie (od 1563 r.).

${ }_{93} \mathrm{~W}$ ziemi chełmskiej obowiązywał system miar lwowskich. War w Krasnymstawie liczył 1106 l, odpowiadał 4 beczkom, z kolei na tę ostatnią składało się 72 garnców (po 3,84 l).

${ }^{94}$ LMAVB, Dział rękopisów, f. 1-421; AGAD, KRSW, sygn. 3195b, s. 258-259. 
z produkcji i sprzedaży wódki oddano w arendę, z której roczny czynsz powinien być wydatkowany na różne potrzeby miejskie, w szczególności naprawę murów i budynków publicznych ${ }^{95}$.

Jedna z podstawowych gałęzi przetwórstwa spożywczego było wysokodochodowe młynarstwo, któremu w Krasnymstawie sprzyjały warunki hydrologiczne w postaci dolin rzecznych Wieprza i jego lewego dopływu Żółkiewki (dawnej Żółkwi). Gospodarka rybna była ściśle związana z rozwojem krasnostawskiego młynarstwa. Wybudowane stawy dostarczały energii wodnej dla młynów i umożliwiały systemowe prowadzenie gospodarki rybnej. Staw Wielki powstał jako pierwszy, najpewniej na początku XV w., gdyż nazwa Krasnystaw właśnie ok. 1410 r. wyparła dawną - Szczekarzów ${ }^{96}$. Staw Wielki znajdował się między właściwym miastem a przedmieściem Zastawie. Łączył się z rzeką Wieprz, dlatego do jego uruchomienia niezbędne było usypanie tamy w postaci wzmocnionej grobli ziemnej. Pełniła ona też funkcję komunikacyjna, gdyż na niej usytuowany był most wiodacy do Bramy Chełmskiej dla przybyszów ze strony Lwowa i Włodzimierza ${ }^{97}$. Z kolei Staw Rzeszowski powstał w końcu XV w., obejmował obszar nad Żółkiewką przyległy do wsi Niemienice. Zapewne w pierwszej połowie XVI w. zbudowano tutaj młyn, co sugeruje zapis w inwentarzu z 1560 r.: „młyn na Żółkwi nowy"98. Młynarstwo krasnostawskie w latach sześćdziesiątych XVI w. rozwijało się dzięki trzem młynom z kołami walnymi, tj. podsiębiernymi. W tym czasie, podobnie jak w kolejnych dziesięcioleciach, pracowały tutaj wyłącznie koła mączne. $\mathrm{Z}$ ich funkcjonowaniem wiązało się istnienie spichlerzy, z których jeden - $\mathrm{z}$ ośmioma komorami, o czym dowiadujemy się z księgi miejskiej pod rokiem 1629, usytuowany był nad Wieprzem nieopodal Bramy Chełmskiej ${ }^{99}$. Właśnie w jego pobliżu na Stawie Wielkim znajdowały się dwa młyny będące własnością królewska. Jeden bardzo duży - z 5 kołami - zlokalizowany był na lewym brzegu Wieprza przy murze miejskim, niedaleko Bramy Chełmskiej. Na przeciwległym brzegu rzeki, przy upuście na grobli pracował drugi

${ }^{95}$ LMAVB, Dział rękopisów, f. 1-430; AGAD, MK, t. 153, k. 369-370.

${ }_{96}$ H. Soroka, Staropolskie pieczęcie Krasnegostawu, „Zapiski Krasnostawskie” 4, 2013, s. 10.

97 Dowiadujemy się o tym z późniejszego inwentarza miasta (połowa XVIII w.); zob. APL, AmKr, sygn. 44, k. 29.

${ }^{98}$ AGAD, ASK, dz. LVI, sygn. 105, k. 16. Pierwotnie należał do wójta krasnostawskiego, ale jeszcze w drugiej połowie XVI w., kiedy już był w gestii starosty, nazywano go „wójtowskim” (od 1570 r. także „rzeszowskim”, a dopiero w XVII w. wyłącznie „rzeszowskim”).

${ }_{99}$ APL, AmKr, sygn. 3, k. 760-761. 
młyn, z 3 kołami. Z kolei przy Stawie Rzeszowskim nad Żółkiewką działał młyn wójtowski, również z 3 kołami ${ }^{100}$. Jak precyzuje inwentarz z 1560 r., młyny obsługiwali pracownicy najemni. Wynagrodzenie roczne zatrudnionych w młynach przy grobli wynosiło 14 złp 12 gr. Dodatkowo młynarze otrzymywali ordynarię w zbożu (9 korców żyta, po korcu pszenicy, jęczmienia i tatarki) i suknie (9 miar) oraz pozwolenie na karmienie wieprzy tucznych (tj. wykastrowanych samców świni domowej) „na omiecinach”, czyli wszelkiego rodzaju plewach i otrębach będących produktem ubocznym przemiału zboża. Nieco gorzej zarabiał robotnik zatrudniony w młynie wójtowskim, któremu wypłacano 6 złp rocznie, ponadto w naturaliach 6 korców żyta i po pół korca pszenicy, jęczmienia i tatarki oraz 6 miar sukna ${ }^{101}$. Specjalnymi względami w zakresie korzystania z młynów starostwa krasnostawskiego cieszył się tutejszy zakon augustianów, który na mocy przywileju królewskiego z 1558 r. był uprawniony do wolnego mlewa słodu i zboża ${ }^{102}$.

Na szczególną uwagę zasługuje rybołówstwo krasnostawskie, do którego nawiązuje zarówno herb z wizerunkiem dwu ryb, jak i sama nazwa miasta, wskazująca na położenie nad zbiornikiem wodnym. Była to profesja wyróżniająca się na tle innych ośrodków miejskich ziemi chełmskiej, co potwierdza organizacja rybaków krasnostawskich w oddzielny cech, którego statut został zatwierdzony przez króla Zygmunta I Starego w 1545 r. ${ }^{103}$ Ryby poławiano w Wieprzu i Żółkiewce oraz w połączonych z nimi dwóch akwenach własności królewskiej, tj. Stawie Wielkim i Stawie Rzeszowskim. Ten ostatni zabezpieczał wyłącznie potrzeby starostów krasnostawskich (wcześniej wójtów). Połowy ryb były na tyle duże, że zaspokajały nie tylko popyt miejscowy, nadwyżki trafiały bowiem nawet do Lublina ${ }^{104}$. Rybołówstwo generowało około połowy starościnskich wpływów fiskalnych z miasta - bez młynarstwa (w 1564 r. - 60\%, w 1569 r. $-54 \%$, w 1572 r. - 47\%). W lustracji z 1564 r. wykazano podatek od rybaków w wysokości 145 złp 27 gr $^{105}$, identyczny wymiar

${ }^{100}$ Lustracja województw ruskiego, podolskiego i betskiego..., s. 12; Жерела..., t. 7, s. 5; AGAD, ASK, dz. LVI, sygn. 105, k. 16. Inwentarz z 1560 r. oraz lustracje z 1564 i 1569 r. wymieniają młyny z identyczną liczbą kół walnych. Z kolei inwentarz z 1572 r. podaje nieco inną liczbę kół młyńskich: przy grobli młyny o 4 i 3 kołach oraz młyn wójtowski o 2 kołach; zob. tamże, k. 66.

${ }^{101}$ AGAD, ASK, dz. LVI, sygn. 105, k. 16v.

102 AGAD, Zbiór dokumentów pergaminowych, rkps 3114; APL, Księgi grodzkie Krasnostawskie (dalej: KgKr), Relacje, manifestacje, oblaty (dalej: RMO), sygn. 3, k. 698-698v.

103 AGAD, MK, t. 67, k. 138-139.

104 BKUL, sygn. 2362, s. 77.

${ }^{105}$ Lustracja województw ruskiego, podolskiego i betskiego..., s. 13. 
odnotowuje lustracja przeprowadzona 5 lat później ${ }^{106}$. Czynsz był uzależniony od pory roku, warunkujacej wielkość połowów. W lustracji z 1564 r. mamy dokładną specyfikację należności z tytułu poławiania ryb w Stawie Wielkim. Jedenastu rybaków stawowych w okresie od stopienia lodów do 23 czerwca płaciło tygodniowo czynsz w wysokości po 14 gr, a tylko jeden z nich - 10 gr. Z kolei „od św. Jana [24 czerwca D.W.] aż do zamarznienia, to jest św. Marcina [11 listopada - D.W.]" w wysokości 7 gr, a jeden rybak - 5 gr. Od 11 listopada do wczesnej wiosny wszyscy rybacy płacili czynsz tygodniowy w wysokości $2 \mathrm{gr}^{107}$. Oprócz rybaków łowiących w Stawie Wielkim mamy też rybaków rzecznych poławiajaccych w Wieprzu i Żółkiewce, przy której - jak już wspomniano - znajdował się Staw Rzeszowski. Poławiano w nim ryby wyłaczne na potrzeby miejscowego starosty ${ }^{108}$. Co prawda w lustracji z 1564 r. nie podano wprost, ilu rybaków łowiło w Wieprzu (a jedynie ogólną wartość uiszczonego przez nich podatku w wysokości 9 złp 9 gr), ale zapewne ich liczba niewiele się zmieniła $\mathrm{w}$ stosunku do inwentarza z 1560 r., w którym odnotowano - oprócz 10 rybaków stawowych także 8 rzecznych ${ }^{109}$. Inwentarz z 1572 r. wykazuje znacznie niższą sumę wpływów podatkowych od rybaków poławiajacych w stawach i rzece Wieprz - 110 złp 11 gr i 9 denarów, chociaż ich liczba wzrosła do 15 stawowych i 4 rzecznych $^{110}$. Rejestry poborowe z lat 1589 i 1591 podają tylko 15 rybaków ${ }^{111}$, być może nie uwzględniają rzecznych.

\section{W dobie kryzysu XVII w.}

Z przekazów źródłowych widać, że Krasnystaw musiał się zmierzyć w nowym stuleciu z niemałymi wyzwaniami, co było po części pokłosiem pożaru, który nawiedził miasto 6 IV 1597 r. ${ }^{112}$ Jego skala musiała być

106 Жерела..., t. 7, s. 5.

${ }^{107}$ Lustracja województw ruskiego, podolskiego i betskiego..., s. 13.

108 Жерела..., t. 3, s. 21.

109 AGAD, ASK, dz. LVI, sygn. 105, k. 15-15v; Lustracja województw ruskiego, podolskiego $i$ betskiego..., s. 13. Inne wydanie tej lustracji, oparte na alternatywnym przekazie źródłowym, pod redakcją M. Hruszewskiego, zawiera wiele różnic w stosunku do opracowania warszawskiego. Dla przykładu określa liczbę rybaków rzecznych na 5; por. Жерела..., t. 3, s. 19.

${ }^{110}$ AGAD, ASK, dz. LVI, sygn. 105, k. 64v-65, 74v. W odrębnym miejscu inwentarza mamy informację o pobraniu 30 złp czynszu dla starosty ze Stawu Rzeszowskiego.

111 AGAD, ASK, dz. I, sygn. 37, k. 924v, 986v.

112 APL, KgKr, RMO, sygn. 2, k. 4. Wizytacja kościelna z 1602 r. wzmiankuje o klęsce powodzi; zob. Archiwum Archidiecezjalne Lubelskie, Rep 60 A, sygn. 149, k. 14v. 
duża, bo jeszcze w $1604 \mathrm{r}$. informowano, że „w mieście pustek niemało jest"113. Narastajacym trudnościom w sposób administracyjny próbowali przeciwdziałać rządzący. Wymownym tego przykładem był przywilej Zygmunta III z 1611 r., w którym rozszerzył, wcześniej obowiąujące tylko w kontekście soli, względne prawo składu na miód przaśny, solone ryby, skóry, łój, wosk, saletrę i inne towary przewożone z Wołynia i Podola w kierunku Lublina i Kazimierza. Musiały one być wystawione na sprzedaż w Krasnymstawie przez 4 dni ${ }^{114}$. Niestety, już w 1612 r. miasto dotknęły kolejne pożary ${ }^{115}$, co należy łączyć $\mathrm{z}$ atakami łupieskimi skonfederowanego wojska z kampanii moskiewskiej, które domagało się zapłacenia żołdu. $Z$ tego też powodu sejm warszawski z następnego roku uwolnił gród nad Wieprzem od obowiązku zapłaty uchwalonych podatków ${ }^{116}$. Na skutek kolejnych klęsk elementarnych Krasnystaw znalazł się w niełatwym położeniu. $\mathrm{Z}$ powodu stacji żołnierskich i wielkiego pożaru, jak zapisano w konstytucji sejmowej z 15 IV 1616 r., miasto „z gruntu zniszczone i zubożone jest" ${ }^{117}$. Z tego też względu sejm, przychylając się do postulatu sejmiku chełmskiego, zwolnił mieszkańców miasta i przedmieść od podatków na okres 2 lat ${ }^{118}$. Lustracja z 1616 r. potwierdza, że zabudowa mieszkalna Krasnegostawu została bardzo mocno zniszczona. W obrębie murów miejskich naliczono 83 większe i 14 mniejsze domy i aż 69 pustych placów, których nie notujemy w analizowanych wcześniej lustracjach z drugiej połowy XVI w. Na przedmieściach odnotowano 55 domów: 20 większych i 35 mniejszych. Informacja o dodatkowych 18 przedmiejskich pustych placach ${ }^{119}$ potwierdza tezę o poważnych ubytkach w zabudowie. W stosunku do 1569 r. liczba niezabudowanych placów na przedmieściach zwiększyła się o 7, a opodatkowanych domów zmniejszyła o 10 . O wiele większy regres można zauważyć w samym mieście, gdzie liczba domów spadła aż o 57, a jak wskazano wyżej - liczba pustych placów wzrosła o 69. Wszystkie analizowane lustracje, także ta z 1616 r., nie dają kompletnego obrazu stanu gospodarczego miasta, gdyż odnotowuja jedynie rzemieślników i kupców zobowiązanych do wnoszenia opłat do skarbu starościńskiego. W przypadku rzemiosła dotyczyło

\footnotetext{
113 APL, AmKr, sygn. 2, k. 37.

114 AGAD, MK, t. 153, s. 367v-368v; AGAD, KRSW, sygn. 3195b, s. 261-264.

115 K. Stołecki, Krasnystaw. Rys historyczny, Puławy 2008, s. 39.

116 J. Ternes, dz. cyt., s. 35.

117 Volumina Constitutionum, t. 3: 1611-1640, cz. 1: 1611-1626, oprac. S. Grodziski,
}

M. Kwiecień, A. Karabowicz, przedm. W. Uruszczak, Warszawa 2010, s. 212.

118 Instrukcja, 8 III 1616 r., w: Akta sejmikowe ziemi chetmskiej..., s. 123; Volumina

Constitutionum, t. 3, cz. 1, s. 212.

119 AGAD, MK, dz. XVIII, t. 47, k. 4. 
to tylko piekarzy, rzeźników i szewców, handlu zaś - sprzedawców soli. W przeciwieństwie do lustracji z lat sześćdziesiątych XVI w. dla początku kolejnego stulecia nie mamy rejestrów poborowych, których informacje mogłyby służyć jako uzupełnienie wiedzy na temat rzemiosła i handlu. Lustratorzy odnotowali, że liczba rzeźników, jeśli przyjąć 24-groszowy przelicznik z jatek - podobnie jak w lustracjach z 1564 i 1569 r. - nie uległa zmianie. Zapłacony przez nich podatek wskazuje na działalność 16 rzeźników. W porównaniu do drugiej połowy XVI w. zmieniły się nieco opłaty na targu miejskim dla rzeźników pozacechowych. $\mathrm{Z}$ tytułu sprzedaży bydła rogatego oddawali sztukę mięsa o wartości 1 gr, za barana zaś przelicznik wynosił 6 denarów. Wyliczenie dla szewców, dla których mamy dodatkowo, oprócz sumy podatkowej (9 złp $18 \mathrm{gr}$ ), wartość jednostkową taryfy - 12 gr (tj. identyczna jak w poprzednich lustracjach i inwentarzu z 1572 r.), pozwala na precyzyjne wskazanie 24 przedstawicieli tej specjalności. Należy podkreślić znaczny rozrost cechu piekarskiego, co znajduje odzwierciedlenie w wyższym zapłaconym przez nich podatku (7 złp 14 gr) oraz podanej dokładnej liczbie piekarzy (28 osób) ${ }^{120}$. Wniosek z tej analizy jest dość oczywisty, wskazuje na dobrą kondycję krasnostawskich rzeźników, szewców i piekarzy. Lustracja ta rzuca również pewne światło na krasnostawskie rybołówstwo. Jego sytuacja nie była już tak korzystna jak w poprzednim stuleciu, o czym np. zaświadcza informacja, że Staw Rzeszowski „przedtem pusto leżał”. Coś musiało się jednak zmienić, ponieważ jak notuja lustratorzy został zastawiony na 3 lata za sumę $250 \mathrm{złp}$, co dawało rocznie 83 złp 10 gr, a więc znacznie więcej niż w 1572 r., kiedy pobrany czynsz z tego akwenu wyniósł $30 \mathrm{złp}^{121}$. Wzrost fiskalizmu w stosunku do poprzedniego okresu dotyczył także użytkowania Stawu Wielkiego, który już od początku XVII w. był puszczony w arendę. Rybacy płacili przez cały sezon 14 gr tygodniowo, a w okresie zimowym zobligowani byli dostarczać ryby „na potrzebę zamkowa” ${ }^{122}$, czyli na rzecz starosty odpowiedzialnego za utrzymanie zamku i zatrudnionych w nich osób. Niestety, nie mamy informacji o liczbie rybaków stawowych. Dotyczy to także rybaków rzecznych, którzy - jak enigmatycznie stwierdzono w lustracji - „od jazów na rzece Wieprzu dają 20 [złp - D.W.]”123.

Również młynarstwo krasnostawskie przeżywało trudności. W 1616 r. działały już tylko 2 młyny, zreszta - jak wspomniano wyżej - oddane

\footnotetext{
120 Tamże, k. 4v.

${ }_{121}$ Tamże, k. 14; por. AGAD, ASK, dz. LVI, sygn. 105, k. 74v.

122 AGAD, MK, dz. XVIII, t. 47, k. 14.

${ }_{123}$ Tamże, k. 5.
} 
w arendę: na Stawie Wielkim ,pod murem miejskim” oraz na Stawie Rzeszowskim ${ }^{124}$. Księga wójtowsko-ławnicza podaje, że dzierżawca młynów w 1604 r. był miejscowy Żyd Izaak, który arendował także Staw Wielki. Właśnie w tym roku, na skutek przerwania grobli, nie otrzymał czynszu od rybaków. Arendarzem młynów w 1607 r. był Żyd Jeleń ${ }^{125}$. Nie tylko lokalni Żydzi byli dzierżawcami krasnostawskich młynów. W $1625 \mathrm{r}$. ich arendarzem był Żyd chełmski Mosko Piesakowicz, a w 1626 r. Żyd wojsławicki Iczko Zelmanik ${ }^{126}$. W tym czasie Krasnegostawu nie omijały również klęski elementarne. W księdze miejskiej czytamy, że w 1625 r. zmagano się z zagrożeniem „morowego powietrza”"27. Podobną sytuację pisarz miejski odnotował w 1630 r., co potwierdza także wizytacja, informując o kilkumiesięcznej zarazie ${ }^{128}$. Skala klęsk elementarnych musiała być znaczna, bo w petitum sejmiku przedsejmowego z 16 XII 1632 r. czytamy: „Za mieszczany krasnostawskimi, którzy różnemi calamitatibus od Pana Boga, powietrzem, ogniem, powodzia gwałtowną sa utrapieni, prośbę wnieść maja panowie posłowie, zniósłszy się z jmp krajczym koronnym starosta krasnostawskim, aby w petitiach swych konsolacyję odnieść mogli"129.

\section{Wytwórcy i kupcy w okresie wielkich wojen}

Nieoczekiwanym ciosem dla miasta był najazd kozacko-tatarski z 1648 r. W następnym roku mieszczanie - z burmistrzem Stefanem Domańskim na czele - zeznali w sądzie grodzkim, że w rezultacie ataku wojsk Bohdana Chmielnickiego zdewastowanych zostało 83 domów, 16 spalonych, a 122 pozostawało niezamieszkałych ${ }^{130}$. W tym też roku nie wybrano czopowego „od piw, od miodów i gorzałek”131. Z uwagi na trudną sytuację mieszkańców miasta szlachta chełmska zgromadzona 11 X 1649 r. na sejmiku przedsejmowym postulowała zwolnienie zrujnowanego Krasnegostawu od podatków na okres 4 lat ${ }^{132}$. W instrukcji sejmikowej z 7 XI 1650 r. znalazł się podobny dezyderat w zakresie

${ }^{124}$ Tamże, k. 14v.

125 APL, AmKr, sygn. 2, k. 33, 52, 215v.

${ }^{126}$ APL, AmKr, sygn. 3, k. 554v-555, 597v-598.

127 Tamże, k. 553v-554.

128 Tamże, k. 836; Archiwum Archidiecezjalne Lubelskie, Rep. 60 A, sygn. 149, k. $188 \mathrm{v}$.

${ }^{129}$ Laudum, 16 XII 1632 r., w: Akta sejmikowe ziemi chetmskiej..., s. 172.

130 APL, KgKr, RMO, sygn. 1, k. 20v.

131 Tamże, k. 525.

${ }^{132}$ Laudum, 11 X 1649 r., w: Akta sejmikowe ziemi chetmskiej..., s. 292. 
zwolnienia podatkowego, bo jak ogólnikowo stwierdzono „miasto Krasnystaw całe prawie zniszczone"133. Jednakże sejm bardzo opieszale reagował na te prośby i sprawa się przeciagała. Tymczasem sytuacja krasnostawskiego rzemiosła i handlu była wręcz katastrofalna, gdyż jak deklaruja przedstawiciele mieszczan w 1650 r.: „Domów, w których handlują i goście w nich stawaja, także rzemiosła robią jest 8 , nie więcej"134. Koresponduje z tym zaprzysiężone zeznanie z następnego roku, wyliczajace tylko 9 opodatkowanych rzemieślników przy zupełnym braku czeladników ${ }^{135}$. Jan Kazimierz 14 V 1651 r. w uniwersale wydanym w Kryłowie w okresie kampanii beresteckiej zakazał wybierania stacji żołnierskich w mieście. Przedstawiając jego fatalny stan, król zaznaczył, że „Krasnystaw od swawolnych rebelizantów naszych, Kozaków niedawnym czasem wniwecz jest spustoszone i obywatele jego przez tę nieznośną i spólną Rzeczpospolitą klęskę, także częste różnych choragwi przechodzenie $\mathrm{z}$ dóbr swoich złupieni do wielkiego ubóstwa przyszli i wielka część się ich rozeszła"136. Dwa lata wcześniej monarcha zezwolił - z powodu zniszczenia mostu na Wieprzu przez Kozaków - na zbudowanie nowego z zachowaniem dotychczasowych prerogatyw fiskalnych ${ }^{137}$.

Rejestry poborowe z 1653 i 1654 r. pokazują bardzo trudną sytuację grodu nad Wieprzem, który dodatkowo został dotknięty zaraza, co wywołało również jego wyludnienie. Spośród rzemieślników czynsz zapłaciło zaledwie 4 mistrzów, a 14 nie uiściło podatku, podobnie jak 3 czeladników i 4 kramarzy soli ${ }^{138}$. Miasto dość szybko zaczęło podnosić się z upadku, co potwierdza jurament z 1655 r., w którym zeznano o zagospodarowaniu części wcześniej opustoszałych domów i łanów. Ponadto oprócz 9 majstrów także 3 czeladników i 1 stolarz uiścili czynsz, z którego wcześniej byli zwolnieni ${ }^{139}$. Niestety, odbudowie potencjału gospodarczego nie sprzyjały kolejne wypadki wojenne: napad kozacko-moskiewski z 1656 r. oraz atak wojsk Rakoczego z 1657 r. Stan zabudowy miejskiej stał się katastrofalny, co w juramencie z 1658 r. zaświadczyli krasnostawianie

${ }^{133}$ Laudum, 7 XI 1650 r., w: tamże, s. 302.

134 APL, KgKr, RMO, sygn. 1, k. 576v.

135 Tamże, k. 655.

136 Vilniaus universiteto biblioteka, Dział rękopisów, f. 48-32751.

137 LMAVB, Dział rękopisów, f. 1-458.

138 APL, KgKr, RMO, sygn. 2, k. 435, 567-567v; APL, KgKr, Rejestry podatkowe, sygn. 1, k. 11-11v. Rejestr łanowego 1654 r. oraz wszystkie późniejsze z XVII w. notuja po stronie retent tylko 1 kramarza sola, powtarzając bezrefleksyjnie - na podstawie tzw. starych kwitów - liczbę rzemieślników i kupców.

139 APL, KgKr, RMO, sygn. 2a, s. 25. 
wraz z burmistrzem Stanisławem Chrościńskim, podając, że „przez incursią Moskwy i Kozaków w roku 1656 od Lublina powracających spalili domów rynkowych in numero trzydzieści i dziewięć, a ulicznych domów in numero dwadzieścia i dziewięć, w drugiem zaś roku przez incursią Węgrów z Kozakami, Wołoszą i Multanami powracającemi spalono domów rynkowych cztery, ulicznych domow in numero siedemnaście, domki podmurne wszystkie i na Przedmieściu Krakowskim Kaspra Piekarza spalono, także zamek i kościół Świętego Ducha i augustyński wespół z inszemi miejskimi domami są ogniem zniesione i zniszczone"140.

W pierwszej połowie lat sześćdziesiątych stan rzemiosła miejskiego z pewnością odbiegał od sytuacji z pierwszego pięćdziesięciolecia XVII w. Lustratorzy wymienili tylko 7 piekarzy, tj. aż o 21 mniej w stosunku do lustracji z 1616 r., dlatego uzyskany podatek wynosił zaledwie 1 złp 26 gr. Z jatek należących do rzeźników i szewców pozyskano czynsz taki jak w 1616 r., tj. 22 złp 12 gr (szacunkowo można założyć 16 rzeźników i 24 szewców) ${ }^{141}$. Na podstawie opisanej sytuacji tych trzech branż wolno przypuszczać, że udało się w pewnym stopniu odbudować potencjał rzemiosła krasnostawskiego po zniszczeniach wojennych (zob. tab. 2).

Tabela 2. Rzemieślnicy krasnostawscy 3 zawodów w latach 1564-1661

\begin{tabular}{|c|c|c|c|c|c|c|}
\hline \multirow[b]{2}{*}{ Rok } & \multicolumn{2}{|c|}{ Rzeźnicy } & \multicolumn{2}{|c|}{ Szewcy } & \multirow{2}{*}{$\begin{array}{c}\text { Piekarze } \\
\begin{array}{c}\text { liczba } \\
\text { osób }\end{array}\end{array}$} & \multirow{2}{*}{$\begin{array}{c}\text { Liczba } \\
\text { osób } \\
\text { ogółem }\end{array}$} \\
\hline & $\begin{array}{l}\text { liczba } \\
\text { osób }\end{array}$ & $\begin{array}{l}\text { liczba } \\
\text { jatek }\end{array}$ & $\begin{array}{c}\text { liczba } \\
\text { osób }\end{array}$ & $\begin{array}{l}\text { liczba } \\
\text { jatek }\end{array}$ & & \\
\hline 1564 & 16 & 16 & 18 & 24 & 14 & 48 \\
\hline 1569 & 16 & 16 & 24 & 24 & 20 & 60 \\
\hline 1616 & 16 & 16 & 24 & 24 & 28 & 68 \\
\hline 1661 & 16 & 16 & 24 & 24 & 7 & 47 \\
\hline
\end{tabular}

Źródło: oprac. własne na podstawie: Lustracja województw ruskiego, podolskiego i betskiego 1564-1565, cz. 1, wyd. K. Chłapowski, H. Żytkowicz, Warszawa 1992, s. 6; Lustracja województwa ruskiego 1661-1665, cz. 3: Ziemie halicka i chetmska, wyd. E. i K. Arłamowscy, W. Kaput, Wrocław 1976, s. 256; Жерела до історї України-Руси, t. 3, wyd. М. Грушевський, Lwów 1900, s. 6; Жерела до історії України-Руси, t. 7, wyd. М. Грушевський, Lwów 1903, s. 2; AGAD, MK, dz. XVIII, t. 47, k. 4 v.

Rzeźnicy pozacechowi (sochacze), podobnie jak wcześniej, uiszczali z tytułu sprzedaży mięsa na rzecz starosty daninę w naturze o wartości 6 denarów od barana oraz od półgrosza do grosza od sztuki bydła. Roczne wpływy podatkowe z miasta na rzecz skarbu starościńskiego wynosiły ogółem tylko 76 złp, a po uwzględnieniu wpływów fiskalnych

${ }^{140}$ APL, KgKr, RMO, sygn. 2, k. 1109v.

${ }^{141}$ Lustracja województwa ruskiego 1661-1665, cz. 3: Ziemie halicka $i$ chetmska, wyd. E. i K. Arłamowscy, W. Kaput, Wrocław 1976, s. 256. 
od rybaków poławiających w Wieprzu (100 złp) i Stawie Rzeszowskim (33 złp 10 gr) - 209 złp 10 gr $^{142}$. Jest to wartość niemal identyczna jak w 1616 r., kiedy stosowny czynsz zamknął się kwotą 209 złp 11 gr i 9 denarów. Brak wpływów od prasołów i rybaków ze Stawu Wielkiego, który najprawdopodobniej wysechł, świadczy o zmniejszeniu się aktywności handlowej miejscowej społeczności (zob. tab. 3). O słabszej kondycji kupiectwa dodatkowo przekonuje rejestr celny komory wodnej w Nowym Dworze z 1662 r. Nie odnotowano w nim żadnego kupca z Krasnegostawu, a dla porównania kupcy z Zamościa występują sześciokrotnie (przewożą m.in. zboże, skóry i wino francuskie) ${ }^{143}$.

Tabela 3. Stan liczebny krasnostawskiego kupiectwa w latach 1563-1661

\begin{tabular}{|c|c|c|c|}
\hline Rok & Liczba prasolów & $\begin{array}{c}\text { Liczba kupców } \\
\text { i kramarzy }\end{array}$ & Ogólem \\
\hline 1563 & 15 & 15 & 30 \\
\hline 1570 & 15 & 15 & 30 \\
\hline 1591 & 17 & 15 & 32 \\
\hline 1616 & 17 & $?$ & $17(?)$ \\
\hline 1661 & - & $?$ & $?$ \\
\hline
\end{tabular}

Źródło: oprac. własne na podstawie: AGAD, ASK, dz. I, sygn. 37, k. 612, 882v, 986v; AGAD, MK, dz. XVIII, t. 47, k. 3.

Uwagę zwraca też wzrastająca rola Żydów, którzy przejęli arendę w zakresie produkcji i sprzedaży wódki. Już od ponad półwiecza dzierżawili także młyny, stawy, karczmy oraz opłaty miejskie (targowe, myto, grobelne $)^{144}$. Należy podkreślić, że uzyskane dochody podatkowe tylko nominalnie nie wykazują różnic $\mathrm{w}$ stosunku do poprzednich dziesięcioleci. Realnie są one dużo niższe, gdyż od początku XVII w. następowała silna deprecjacja złotego, a jednocześnie wysoka inflacja. Jak ustalił Władysław Adamczyk, między okresem 1611-1620 a 1661-1670 ceny żyta w pobliskim Lublinie wzrosły o $470 \%$, a piwa o $150 \%{ }^{145}$. Temu

${ }^{142}$ Tamże, s. 256, 262. W wyliczeniach nie uwzględniono wpływów fiskalnych z targowego (brak wyszczególnienia pieniężnego w arendzie - 15 złp?).

${ }^{143}$ Regestr celny nowodworski: tak dolny jako $i$ górny na wiosnę i jesień in anno 1662, wyd. S. Kazusek, Kielce 2011, s. 71, 87, 107-109, 112. Jak ustaliła H. Obuchowska-Pysiowa na podstawie ksiag celnych komory warszawskiej dla 26 lat (1605-1651) partycypacja kupców Krasnegostawu w wywozie zboża wyniosła 207 łasztów; por. taż, Handel wiślany w pierwszej połowie XVII wieku, Wrocław 1964, s. 149-150.

${ }^{144}$ Lustracja województwa ruskiego..., s. 262.

145 W. Adamczyk, Ceny w Lublinie od XVI do końca XVIII wieku, Lwów 1935, s. $129,131$. 
zjawisku towarzyszył państwowy drenaż fiskalny w zakresie podatków, których pobór - w warunkach permanentnego zagrożenia wojennego lawinowo wzrósł. Wielu mieszkańców popadało w długi i sprzedawało swoje nieruchomości. Z powodu zakazu osiedlania się Żydów w mieście głównymi wierzycielami byli kanonicy katedralni i bonifratrzy, którzy przybyli do Krasnegostawu prawdopodobnie w 1649 r. ${ }^{146} \mathrm{~W}$ latach pięćdziesiątych XVII w. duchowieństwo wzbogaciło się o nowe parcele z domami oraz karczmy, ogrody miejskie i grunty podmiejskie. Nieruchomości obciążone długami kupowano, a nawet zawłaszczano ${ }^{147}$. Zubożeni mieszczanie oskarżali sufragana chełmskiego Mikołaja Cytreńskiego o nieuprawnione włączanie nabytych dóbr do kompleksu jurydyk kościelnych, na których osadzeni poddani zajmowali się handlem, nie uiszczając z tego tytułu podatków do kasy miejskiej ${ }^{148}$. Dodatkowo kler $\mathrm{w}$ tym okresie był beneficjentem nadań, jak chociażby konwent bonifratrów, który od miejscowej szlachty otrzymał uposażenie w postaci gruntów o areale 2 łanów na Przedmieściu Lubelskim ${ }^{149}$. Przeprowadzona w 1661 r. lustracja informuje o 4,75 łanach duchowieństwa „za przywilejami KJM" wyjętych spod jurysdykcji miejskiej ${ }^{150}$. Zakon augustianów wykorzystał zamęt wojenny okresu powstania Chmielnickiego i potopu do wręcz samowolnego zajmowania części przyległych do klasztoru placów i ulic, naruszając przy tym prawo przechodu i przejazdu. W kolejnych dziesięcioleciach stan posiadania zakonników powiększył się o gospodarstwa z 6 domkami na przedmieściu Zastawie ${ }^{151}$. Libertowane nieruchomości, wyjęte spod prawa miejskiego, osłabiały miasto pod względem gospodarczym. Monitowana przez mieszczan szlachta na sejmikach chełmskich w 1669 i 1670 r. postulowała konieczność przeprowadzenia stosownej rewizji, która dałaby możliwość wyznaczenia nowej bazy podatkowej danin państwowych ${ }^{152}$.

${ }^{146}$ I. Pietrzkiewicz, Miser Res Sacra. Bonifratrzy w dawnej Rzeczypospolitej, Kraków 2009 , s. 57

${ }^{147}$ APL, KgKr, RMO, sygn. 3, k. 319v-321v; Lustracja województwa ruskiego..., s. $264-265$.

148 APL, KgKr, RMO, sygn. 6, k. 324v-325; Lustracja województwa ruskiego..., s. $263-265$.

${ }^{149}$ Lustracja województwa ruskiego..., s. 266-267.

150 Tamże, s. 256.

151 APL, KgKr, RMO, sygn. 3, k. 576v-577, 698; APL, KgKr, RMO, sygn. 12, k. 624. Już w XVI w. zakonnicy posiadali - obok nieruchomości w mieście - ogrody z zagrodami na przedmieściu Zakręcie.

${ }_{152}$ Нацыянальны гістарычны архіў Беларусі, Мінск, Księgi grodzkie chełmskie, f. 1740, op. 1, dz. 7, Instrukcja sejmiku przedsejmowego, 20 VIII 1669 r., k. 246v; APL, Księgi grodzkie chełmskie, RMO, sygn. 89, Instrukcja sejmiku przedsejmowego, 


\section{Agraryzacja i depopulacja}

Prawdziwym utrapieniem dla mieszkańców były stacje żołnierskie z okresu wojen Rzeczypospolitej z Rosją i Turcja. 3-4 października 1663 r. w mieście stacjonowała choragiew kozacka rotmistrza Stanisława Iwanowskiego. Całkowita wartość kosztów tej stacji żołnierskiej zamyka się w kwocie 304 złp 12 gr $^{153}$. Krasnystaw, jako miasto królewskie, zobligowany był do hiberny, która od $1667 \mathrm{r}$. płacono w pieniądzu. W $1671 \mathrm{r}$. choragiew chorążego chełmskiego Jana Karola Romanowskiego pobrała aż 1447 złp 18 gr, tj. niemal trzykrotnie więcej od przyznanej kwoty ${ }^{154}$. Na domiar złego w tym czasie doszło do wielu pożarów, które jeszcze bardziej nadwyrężyły ekonomikę miasta, spychając rzemieślniczo-handlowy Krasnystaw do roli ośrodka agrarnego z dominacją mieszczan-rolników. Przekonuje o tym także rozbudowa nowo powstałych przedmieść (Piaski, Zadworze, Zakościele), na których głównie prowadzono gospodarstwa rolne. Pożary miały miejsce w latach 1663 (25/26 marca), 1665 (24 lutego i 16 marca), 1666 (28 marca), 1667 (21 i 23 października), 1668 (25 kwietnia i 7 maja), 1671 (22/23 marca, 22 czerwca i 22/23 listopada) i 1672 (4/5 lutego i 21/22 maja). Ogień strawił w sumie 160 domów w mieście i na przedmieściach, z których 1/3 stanowiły szynki. Ponadto spaliło się 5 folwarków oraz browar z słodownią ${ }^{155}$.

Klęski elementarne, które dotknęły Krasnystaw, spowodowały, że szlachta ziemi chełmskiej w lipcu $1671 \mathrm{r}$. podjęła uchwałę zwalniająca pogorzelców od podatków na okres 4 lat ${ }^{156}$. W następnym roku mieszczanie posiadajaccy dobra ziemskie zostali uwolnieni od uczestnictwa w pospolitym ruszeniu na wojnę z Turcją ${ }^{157}$. Od 29 IX 1672 r. Krasnystaw był miejscem kilkudniowego postoju kilkutysięcznych oddziałów koronnych hetmana wielkiego koronnego Jana Sobieskiego ${ }^{158}$. Stacjonujące wojsko musiało wykazać się dużą dyscyplina, w sądzie grodzkim nie zachowały się bowiem żadne skargi mieszczan tego dotyczące. Nie zawsze jednak tak było, w 1684 r. łączny koszt prowiantu wydanego wojsku brandenburskiemu wyniósł 1206 złp 10 gr. Ponadto - jak

22 I 1670 r., s. 88. Rewizje podatkowe zostały przeprowadzone w latach osiemdziesiątych i dziewięćdziesiątych do wyznaczenia aktualnej podstawy poboru podymnego.

${ }_{153}$ APL, KgKr, RMO, sygn. 4, k. 229v-230.

154 APL, KgKr, RMO, sygn. 6, k. 613-615v.

155 APL, KgKr, RMO, sygn. 4, k. 203, 811v; APL, KgKr, RMO, sygn. 5, k. 81v-82, 927v-928; APL, KgKr, RMO, sygn. 6, k. 756-756v, 1108v.

156 APL, Księgi grodzkie chełmskie, RMO, sygn. 90, Laudum sejmiku, 9 VII 1671 r., s. $1269-1270$.

${ }^{157}$ APL, KgKr, RMO, sygn. 6, k. 1213v-1214.

158 J. Ternes, dz. cyt., s. 41. 
zeznali mieszczanie w sądzie grodzkim - „piece, także i okna w kilku miejscach potłuczono, z których szkoda nie oszacowana"159.

Stacje żołnierskie oraz częste klęski elementarne przez długi czas uniemożliwiały wyjście z głębokiego kryzysu gospodarczego. Jurament z 1671 r. notuje zaledwie 13 rzemieślników, w tym 1 stolarza ${ }^{160}$. Nieco więcej światła na ówczesną kondycję krasnostawskiego rzemiosła rzuca wprowadzony w 1673 r. podatek szelężnego, który - podobnie jak czopowe - był uiszczany od napojów alkoholowych. Czopowe, przejęte od połowy XVII w. przez sejmiki, dowolnie nim dysponujace, spowodowało wymierny uszczerbek skarbu koronnego w zakresie finansowania potrzeb wojennych. Te niedobory chciano uzupełnić szelężnym, którego stawka wynosiła 10\% wartości sprzedawanych napojów alkoholowych $^{161}$. Niestety, dla siedemnastowiecznego Krasnegostawu zachował się jedynie pierwszy wykaz szelężnego. Za dwa kwartały, tj. między 1 V a 31 X 1673 r. uzyskano wpływy na poziomie 675 złp 24 gr i 13 denarów ${ }^{162}$. Nie była to wartość duża, jeśli porównamy do Chełma 870 złp 4 gr i 4 denary, a zwłaszcza Zamościa - 3147 złp 19 gr. Niewiele mniejszy podatek niż Krasnystaw wniósł Szczebrzeszyn - 601 złp 24 gr i 4 denary ${ }^{163}$. Za kolejne dwa kwartały, tj. od 1 XI 1673 do 30 IV 1674 r. zapłacono 491 złp 5 gr i 8 denarów ${ }^{164}$. I tutaj znowu zdecydowanie większe wpływy podatkowe wygenerowano w Zamościu - 1930 złp 25 gr i 7 denarów, z kolei w Szczebrzeszynie - 456 złp 28 gr i 14 denarów ${ }^{165}$. Dla Chełma nie przetrwał analogiczny wykaz. Z drugiej połowy XVII w. dysponujemy jeszcze juramentem złożonym w sądzie grodzkim w $1700 \mathrm{r}$., z którego dowiadujemy się, że w ciagu jednego kwartału, tj. między 1 XI 1699 r. a końcem stycznia roku następnego w Krasnymstawie sporzadzono 90 warów piwa oraz 6 beczek i 30 garnców miodu ${ }^{166}$. Gdyby przyjać proporcjonalne doszacowanie za kolejne 3 kwartały (co daje podstawę porównawczą dla lat sześćdziesiątych XVI w. - 1563 r. - 262,5 warów piwa i 236 beczek miodu), można założyć, że w roku podatkowym

159 APL, KgKr, RMO, sygn. 12, k. 254v-255v.

${ }^{160}$ APL, KgKr, RMO, sygn. 6, k. 756v; por. R. Kozyrski, Miasta i mieszczaństwo $w$ dokumentach sejmiku ziemi chetmskiej 1648-1717, „Rocznik Chełmski” 10, 2006, s. 22, błędnie informuje, że w 1673 r. w Krasnymstawie działało tylko 4 rzemieślników.

${ }^{161}$ R. Kozyrski, Szlachta, Kościót, podatki. Czopowe i szelężne w ziemi chetmskiej w XVII-XVIII $w$., „Rocznik Chełmski” 15, 2011, s. 128-129.

162 AGAD, ASK, dz. I, sygn. 69, k. 536-536v.

163 Tamże, k. 493-493v, 501v-502, 539-539v, 541v-542.

${ }_{164}$ Tamże, k. 519-519v. Arendą propinacji zajmował się Żyd Szmujło Gierszowicz i z tego też względu był zaangażowany w pobór szelężnego.

165 Tamże, k. 520v, 522v-523.

${ }^{166}$ APL, KgKr, Rejestry podatkowe, sygn. 1, k. 365. 
1669/1700 wyprodukowano ok. 360 warów piwa pełnego oraz ok. 26 beczek miodu. Oznacza to wzrost produkcji piwa, a z drugiej strony znacznie słabszą kondycję producentów miodu (spadek 89\%). Miód pitny w tych czasach był trunkiem luksusowym i drogim, dlatego jego niska produkcja dowodzi znaczącej pauperyzacji mieszkańców Krasnegostawu.

Z perspektywy wojen i towarzyszących im klęsk elementarnych najdotkliwsze, ponieważ skutkujące spadkiem produkcji oraz obrotów handlowych, były straty demograficzne wśród rzemieślników i kupców. Uchwalone po wielkich wojnach na sejmie w 1662 r. pogłówne, z przeznaczeniem na zapłatę żołdu skonfederowanemu wojsku, wyjątkowo precyzyjnie identyfikuje 1396 mieszkańców Krasnegostawu, z tego 27 Żydów ${ }^{167}$. Oznacza to, że potencjał demograficzny miasta (po dodaniu nieuwzględnionych ludzi starszych oraz małych dzieci ${ }^{168}$ ) obejmował ok. 2000 mieszkańców i znacząco przewyższał stan z okresu największej prosperity połowy XVI w. Rejestr pogłównego z 1673 r. wyliczył już jednak 1041 mieszkańców ${ }^{169}$, a rejestr z 1676 r. - tylko $469^{170}$. Co prawda w latach siedemdziesiątych XVII w. pobór pogłównego był już z reguły mniej rzetelny ${ }^{171}$, ale gdy porównamy wyodrębnioną z rejestrów ludność zamieszkała w kompleksie zamkowym, a te wartości podawano nadal z wyliczeniem poszczególnych osób, to niewątpliwie przez długi czas tendencja demograficzna rysuje się niekorzystnie (1662 r. - 135 osób, 1673 r. - 107, 1676 r. - 61). Potwierdza to także liczba osób zamieszkałych w jurydyce duchownej (w 1662 r. - 403, w 1673 r. - 328, w 1676 r. - 125). Wyłaniający się ze źródeł obraz stanu populacyjnego miasta koresponduje ze stanowiskiem Krzysztofa Mikulskiego. Zwrócił on uwagę, na przykładzie Torunia, że długotrwałe załamanie demograficzne nie zaczęło się w okresie wojen, lecz właśnie dopiero kilkanaście lat po ich zakończeniu ${ }^{172}$. Dodajmy, że szybko dźwigające się po wojennych

${ }^{167}$ AGAD, ASK, dz. I, sygn. 71, k. 111-112; APL, KgKr, RMO, sygn. 4, k. 394-394v. Rejestr pominął, zgodnie z uchwała sejmowa, dzieci do lat 10 oraz osoby starsze i żebraków.

${ }^{168}$ Zob. C. Kuklo, Demografia Rzeczypospolitej przedrozbiorowej, Warszawa 2009, s. 360-361. W literaturze przedmiotu, z racji nieuwzględniania w rejestrach pogłównego dzieci do lat 10, proponuje się doszacowanie od ok. 1/3 do $2 / 5$.

169 AGAD, ASK, dz. I, sygn. 71, k. 169-169v, 187v-188; APL, KgKr, Rejestry podatkowe, sygn. 1 , k. 321-321v.

${ }^{170}$ Biblioteka Książąt Czartoryskich w Krakowie, sygn. 1099, s. 247-249, 266, 268. Bez uwzględnienia jurydyki duchownej zarejestrowano 344 mieszkańców.

${ }^{171}$ R. Rybarski, Skarb i pieniadz za Jana Kazimierza, Michała Korybuta $i$ Jana III, Oświęcim 2015, s. 152-154.

${ }_{172}$ Polska na tle Europy XVI-XVII wieku. Konferencja Muzeum Historii Polski, Warszawa 23-24 października 2006, Warszawa 2007, s. 81 (głos w dyskusji). 
zgliszczach miasto w 1661 r. dysponowało 147 domami, ale 4 lata później już tylko 72, w 1676 r. zaś zaledwie $40^{173}$. Przełamanie niekorzystnego trendu obserwujemy w Krasnymstawie w latach osiemdziesiatych XVII w. Zapewne dzięki usprawnieniu ochrony przeciwpożarowej udało się uniknać kolejnych poważniejszych pożarów. Te, które się zdarzały, nie przybierały już tak dużych rozmiarów ${ }^{174}$. Po części był to skutek zmian urbanistycznych w kierunku wznoszenia, zwłaszcza w rynku, posesji murowanych. Poprawie infrastruktury miejskiej służył dyplom królewski z 18 VI 1681 r., w którym pozwolono na wycinkę drzew z pobliskiego lasu celem reparacji mostów i zamku ${ }^{175}$. W warunkach względnej stabilizacji politycznej Krasnystaw powoli podnosił się z głębokiego kryzysu. Dokonana w 1684 r. rewizja miasta na potrzeby ustalenia rzeczywistej podstawy podatkowej uchwalonego podymnego wykazała w zespole miejskim 216 domów (z tego 82 na przedmieściach) ${ }^{176}$. Kolejny pobór podymnego z 1692 r., dokonany także na podstawie rewizji, określił liczbę domów na 234 (103 w strefie podmiejskiej) ${ }^{177}$. Na ich podstawie możemy przekonująco stwierdzić, że tkanka mieszkalna miasta została odbudowana. Bynajmniej nie towarzyszył temu równie intensywny wzrost liczby ludności w wieku produkcyjnym. Zachowany rejestr pogłównego z 1696 r. informuje o 545 mieszkańcach (bez duchowieństwa ${ }^{178}$, a więc istotnie więcej niż 20 lat wcześniej. Znaczną dysproporcję między liczbą domów i ludności można częściowo wyjaśnić dużą grupą małych dzieci (tzw. powojenna kompensata urodzeń), których nie uwzględniali poborcy pogłównego. Po maksymalnym doszacowaniu (2/5) i dodaniu seniorów oraz kilkudziesięcioosobowego personelu duchownego z jego służbą domowa, ówczesną populację miasta możemy określić na blisko 900 osób. Ponadto, jak wskazał Andrzej Wyrobisz, po klęskach elementarnych w pierwszej kolejności zajmowano się odbudową domostw i gospodarstw, następnie warsztatów rzemieślniczych, a na końcu kapitałochłonnych zakładów przetwórczych, jak młyny czy

${ }^{173}$ Lustracja województwa ruskiego..., s. 257; AGAD, ASK, dz. I, sygn. 65, k. 521, 540. Lustratorzy, najpewniej po ujęciu abiurat, dopiero ok. 1665 r. podali liczbę domów.

${ }_{174}$ APL, KgKr, Relacje, sygn. 16, k. 669-669v; APL, KgKr, RMO, sygn. 22, k. 801v-802. Pożar z 7 I 1690 r. tym razem dotyczył 2 gospodarstw z przedmieścia Zastawie. W nocy z 7 na 8 VI 1698 r. spaliły się 3 domy w mieście, 26 sierpnia - 2 posesje, a $31 \mathrm{~V} 1699$ r. kolejne 2.

${ }^{175}$ APL, KgKr RMO, sygn. 10, k. 729v. Pisarz grodzki w oblatowanym przywileju omyłkowo podał rok 1671 (sic!).

176 APL, KgKr RMO, sygn. 12, k. 624.

177 Центральний державний історичний архів України, м. Львів, f. 181 (Lanckorońskich), op. 2, nr 1058, k. 4-4v.

178 APL, KgKr, Rejestry podatkowe, sygn. 1, k. 179-179v. 
gorzelnie $^{179}$. Można pokusić się o postawienie tezy, choć z końca XVII w. nie zachowały się kompletne źródła skarbowe ukazujące aktywność handlową i rzemieślnicza, że potencjał gospodarczy Krasnegostawu w końcu tzw. srebrnego wieku poprawił się, niemniej odbiegał od poziomu z pierwszej połowy tego stulecia, a ponad wszelką wattpliwość wypadał gorzej w porównaniu do drugiej połowy XVI w.

$$
* * *
$$

W okolicznościach rozwoju gospodarki towarowo-pieniężnej i przyrostu demograficznego na obszarach wiejskich, co obserwujemy jeszcze przez większą część XVI w., pomyślnie rozwijały się rzemiosło i handel, podstawowe zajęcia miejskie. Ówczesny Krasnystaw był średnim miastem o znaczeniu regionalnym. Korzystał z europejskiej i krajowej koniunktury oraz aktywizacji gospodarczej ziemi chełmskiej. Był rozwiniętym ośrodkiem rzemieślniczym, znaczącym w zakresie handlu zbożem, skórami i rybami, w mniejszym stopniu solą i innymi artykułami. Działało tutaj wiele zakładów przetwórstwa płodów rolnych, jak młyny, browary, słodownie, gorzelnie czy rzeźnie. Miasto było ważnym punktem tranzytowym na szlaku z Rusi Czerwonej i Wołynia. Jednak już w ostatniej ćwierci XVI w. możemy odnotować symptomy kryzysu gospodarczego. Henryk Samsonowicz ustalił, że miastom w tym czasie najbardziej dawała się we znaki konkurencja ze strony szlachty, która w coraz większych folwarkach rozbudowywała rzemiosło dworskie. Niejako w sposób naturalny najbardziej wzrastała produkcja w młynarstwie, piekarstwie i piwowarstwie. Przy dworach folwarcznych zatrudniano także rzemieślników z innych branż, część na stałe, innych zaś sezonowo ${ }^{180}$. Równolegle nasilał się przymus propinacyjny oraz pańszczyzna, której wymiar był największy w folwarkach królewskich ${ }^{181}$. W tych przesłankach zawiera się odpowiedź na obserwowane w źródłach zmniejszenie potencjału rzemiosła krasnostawskiego w ostatniej ćwierci

${ }^{179}$ A. Wyrobisz, Zagadnienie upadku rzemiosta i kryzysu gospodarczego miast $w$ Polsce: wiek XVI czy XVII? (w zwiazku z pracami Maurycego Horna, Skutki ekonomiczne najazdów tatarskich z lat 1605-1633 na Ruś Czerwona, Wrocław 1964; oraz, Rzemiosto miejskie województwa betskiego w pierwszej połowie XVII wieku: zagadnienie kryzysu gospodarczego Rzeczypospolitej szlacheckiej w XVII wieku, Wrocław 1966), PH, t. 58, 1967, nr 1, s. 135.

${ }^{180}$ H. Samsonowicz, Rzemiosto wiejskie $w$ Polsce $w$ XIV-XVI w., Warszawa 1954, s. $106-107$.

${ }^{181}$ B. Kwiatkowski, Folwarki Lubelszczyzny. Historia rozwoju i zabudowy, Lublin 2012 , s. 36. 
tzw. złotego wieku. Potwierdzają to wyliczenia Maurycego Horna dla pobliskiego województwa bełskiego, z których wynika, że w 13 tamtejszych miastach w ciagu 40 lat (1578-1618) liczba rzemieślników spadła o $35 \%{ }^{182}$. Oczywiście dochodziły także czynniki doraźne, jak klęski elementarne w postaci chociażby pożarów z 1575 i 1597 r., które dodatkowo nadszarpnęły potencjał wytwórców Krasnegostawu.

Z kolei w zakresie handlu szlachta rozwijając gospodarkę folwarczno-pańszczyźniana, organizowała spław zboża za pośrednictwem kupców gdańskich, cieszac się stosownymi zwolnieniami celnymi. W Gdańsku bardzo często nabywano artykuły rzemieślnicze pod zastaw płodów rolnych, które zobowiązywano się dostarczyć w przyszłości. Mieszczanie, którzy w XVI w. byli znaczącymi kontrahentami spławu, w kolejnym stuleciu - z nielicznymi wyjątkami - stracili dotychczasowa pozycję na rzecz szlachty, dysponującej tanią siłą chłopów pańszczyźnianych ${ }^{183}$. Dla Krasnegostawu wymownie potwierdza to regestr celny nowodworski z 1662 r., w którym nie wymieniono żadnego miejscowego kupca. Również krasnostawskie jarmarki przeżywały trudności. Na wyszczególnione symptomy regresu gospodarczego nakłada się zjawisko kurczenia się odległości pomiędzy miastami, których nazbyt gęsta sieć spychała na margines słabsze organizmy. Stało się tak na skutek rozwoju procesu lokacji miast prywatnych i nadawania nowych przywilejów w zakresie uprawiania handlu i rzemiosła. Najbardziej dobitnym przykładem był założony w 1580 r. pobliski Zamość, który zachwiał dotychczasowa pozycja ekonomiczna Krasnegostawu. Pierwsza połowa XVII w. to czas wielkiego pożaru i epidemii, które walnie przyczyniły się do spadku potencjału królewskiego miasta. Żydzi, zaangażowani w obrót artykułami rolnymi i leśnymi, przejęli w arendę przetwórstwo i pobór podatków. Taki stan rzeczy obserwujemy także przez większą część drugiej połowy XVII stulecia, co ma związek z nasileniem się klęsk elementarnych, na czele z wojnami, które zapoczątkowało powstanie Bohdana Chmielnickiego. Towarzyszyła temu bezprecedensowa dewastacja oraz

${ }^{182}$ M. Horn, Rzemiosło województwa betskiego w pierwszej połowie XVII wieku. Zagadnienie kryzysu gospodarczego Rzeczypospolitej szlacheckiej $w$ XVII wieku, Wrocław 1966, s. 159-160. Autor nazbyt lapidarnie tłumaczy ówczesny spadek liczby rzemieślników ich rozproszeniem z powodu migracji do nowo zakładanych miast województwa bełskiego.

${ }_{183}$ Z. Górczak, Poczatki oraz funkcjonowanie targów i jarmarków w średniowiecznej Polsce, w: Targi, jarmarki i odpusty. Wyktady popularnonaukowe zorganizowane $w$ ramach X Ogólnopolskiego Festiwalu Kultury Stowiańskiej i Cysterskiej $w$ Ladzie nad Warta w dniach 31 maja - 1 czerwca 2014 roku, red. M. Brzostowicz, M. Przybyła, J. Wrzesiński, Poznań 2014, s. 39-41; Z. Czownicki, Spław rzeczny na Sanie czasów nowożytnych, Rzeszów 2009, mps w zbiorach autora, s. 164-165. 
depopulacja, a trzeba też pamiętać, że ludność wiejska była rezerwuarem siły roboczej i wzrostu demograficznego miast. W tych warunkach niemal zamarła legalna działalność rzemieślniczo-handlowa. Do tego dochodziło, dotkliwe dla rękodzielników i kupców, powiększanie jurydyk kościelnych. Po czasach wielkich zmagań wojennych połowy XVII w. Krasnystaw zadziwiająco szybko podnosił się z upadku, o czym po części przekonuje stan rzemiosła i zabudowy mieszkalnej, a zwłaszcza znaczna liczba mieszczan na początku lat sześćdziesiątych (m.in. w efekcie powojennych powrotów). Niebawem jednak musiano zmierzyć się $\mathrm{z}$ kolejnymi klęskami w postaci serii kilkunastu pożarów w latach 1663-1672 oraz zubożającymi miasto stacjami żołnierskimi. Konsekwencją był postępujący kryzys demograficzny, zapewne częściowo na skutek migracji rzemieślników i kupców do pobliskiego Zamościa, a także ruralizacja ekonomiki miasta, o czym dodatkowo przekonuje rozrost przedmieść. Materiały źródłowe z tego okresu w bardzo ograniczonym stopniu pokazują potencjał kupców i rękodzielników. Przeprowadzone szacunki sugerują nawet 89-procentowy ubytek rzemieślników. Sytuacja miasta w dziedzinie rzemiosła i handlu w drugiej połowie XVII w. w dużym stopniu odzwierciedlała ogólnopolskie i regionalne tendencje. Lubelskie jarmarki w tym okresie również nie miały już takiego znaczenia jak dawniej. Zmniejszenie popytu na zboże oraz reorientacja geograficzna handlu europejskiego spowodowały spadek znaczenia Bałtyku na korzyść strefy atlantyckiej. To kolejny determinant tzw. kryzysu XVII w., który - jak wykazano na przykładzie Krasnegostawu - rozpoczął się w części miast w końcowym kwartale poprzedniego stulecia.

\section{Bibliografia}

Adamczyk W., Ceny w Lublinie od XVI do końca XVIII wieku, Lwów 1935.

Baranowski B., Polska karczma, restauracja, kawiarnia, Wrocław 1979.

Baszanowski J., Handel wołami w Polsce $w$ XVI-XVIII w., Szczęsne 2017.

Berkowski W.H., Wotyńsko-gdańskie kontakty handlowe w XVI - pierwszej połowie XVII wieku, „Acta Historica Universitatis Klaipedensis” 14, 2007, s. $45-54$.

Bogucka M., Samsonowicz H., Dzieje miast i mieszczaństwa w Polsce przedrozbiorowej, Wrocław 1986.

Boroda K., Geografia gospodarcza Królestwa Polskiego w XVI wieku, Białystok 2016.

Boroda K., O przydatności rejestrów poborowych $z$ XVI wieku $w$ badaniach demograficznych, „Przeszłość Demograficzna Polski” 33, 2014, s. 21-38.

Charewiczowa Ł., Handel średniowiecznego Lwowa, Lwów 1925. 
Czownicki Z., Spław rzeczny na Sanie czasów nowożytnych, Rzeszów 2009, mps w zbiorach autora.

Górczak Z., Poczatki oraz funkcjonowanie targów i jarmarków w średniowiecznej Polsce, w: Targi, jarmarki i odpusty. Wyktady popularnonaukowe zorganizowane w ramach X Ogólnopolskiego Festiwalu Kultury Stowiańskiej $i$ Cysterskiej $w$ Ladzie nad Warta $w$ dniach 31 maja - 1 czerwca 2014 roku, red. M. Brzostowicz, M. Przybyła, J. Wrzesiński, Poznań 2014, s. 12-42.

Guzowski P., Poniat R., Przeliczniki demograficzne $w$ szacunkach zaludnienia miast $w$ Królestwie Polskim $w$ drugiej połowie XVI wieku, „Przeszłość Demograficzna Polski” 37, 2005, nr 2, s. 77-93.

Horn M., Rzemiosło województwa betskiego w pierwszej połowie XVII wieku. Zagadnienie kryzysu gospodarczego Rzeczypospolitej szlacheckiej $w$ XVII wieku, Wrocław 1966.

Hoszowski S., Handel Gdańska w okresie XV-XVIII wieku, „Zeszyty Naukowe Wyższej Szkoły Ekonomicznej w Krakowie” 1960, nr 11, s. 3-71.

Janeczek A., Miasta prywatne na Rusi Koronnej do końca XV wieku, RDSG, t. 77, 2016, s. 143-177.

Jusiak P., Krasnystaw na szlakach handlowych w średniowieczu, „Zapiski Krasnostawskie" 4, 2013, s. 21-31.

Karpiński A., W walce z niewidzialnym wrogiem. Epidemie chorób zakaźnych $w$ Rzeczypospolitej XVI-XVIII wieku i ich nastepstwa demograficzne, spoteczno-ekonomiczne $i$ polityczne, Warszawa 2000.

Kozyrski R., Miasta i mieszczaństwo $w$ dokumentach sejmiku ziemi chełmskiej 1648-1717, „Rocznik Chełmski” 10, 2006, s. 21-35.

Kozyrski R., Szlachta, Kościót, podatki. Czopowe $i$ szelężne $w$ ziemi chełmskiej $w$ XVII-XVIII w., „Rocznik Chełmski” 15, 2011, s. 125-137.

Kuklo C., Demografia Rzeczypospolitej przedrozbiorowej, Warszawa 2009.

Kumor B., Przeniesienie stolicy biskupiej z Chetma do Krasnegostawu (1490), „Archiwa Biblioteki i Muzea Kościelne” 49, 1984, s. 369-380.

Kwiatkowski B., Folwarki Lubelszczyzny. Historia rozwoju i zabudowy, Lublin 2012.

Majer J., Obraz postęu nauki lekarskiej, o ile nań wptynęty pisma polskie, lub przez Polaków w trzech ostatnich latach wydane, Kraków 1840 (odb.: „Rocznik Wydziału Lekarskiego w Uniwersytecie Jagiellońskim” 3).

Małecki J.M., Zwiazki handlowe miast polskich z Gdańskiem w XVI i pierwszej połowie XVII wieku, Wrocław 1968.

Manikowski A., Zmiany czy stagnacja? Z problematyki handlu polskiego $w$ drugiej połowie XVII wieku, PH, t. 64, 1973, nr 4, s. 771-791.

Mączak A., Samsonowicz H., Zientara B., $Z$ dziejów rzemiosła $w$ Polsce, Warszawa 1954.

Myśliński K., Lublin a handel Wrocławia z Rusia, „Rocznik Lubelski” 3, 1960, s. $5-36$.

Obuchowska-Pysiowa H., Handel wiślany w pierwszej połowie XVII wieku, Wrocław 1964.

Pietrzkiewicz I., Miser Res Sacra. Bonifratrzy w dawnej Rzeczypospolitej, Kraków 2009. 
Polska na tle Europy XVI-XVII wieku. Konferencja Muzeum Historii Polski, Warszawa 23-24 października 2006, Warszawa 2007.

Rybarski R., Handel i polityka handlowa Polski w XVI stuleciu, t. 1: Rozwój handlu i polityki handlowej, Poznań 1928; t. 2: Tablice i materiaty statystyczne, Poznań 1929.

Rybarski R., Skarb i pieniadz za Jana Kazimierza, Michała Korybuta i Jana III, Oświęcim 2015.

Samsonowicz H., Przemiany osi drożnych w Polsce późnego średniowiecza, $\mathrm{PH}$, t. $64,1973, \mathrm{nr} 4$, s. $697-716$.

Samsonowicz H., Rzemiosto wiejskie w Polsce $w$ XIV-XVI w., Warszawa 1954. Simpson S., History and Mythology of Polish Vodka: 1270-2007, „Food \& History" 8, 2010, nr 1, s. 121-148.

Soroka H., Staropolskie pieczęcie Krasnegostawu, „Zapiski Krasnostawskie” 4, 2013, s. 7-20.

Stołecki K., Krasnystaw. Rys historyczny, Puławy 2008.

Szczygieł R., Hrubieszów w okresie staropolskim. Charakterystyka etapów rozwoju miasta, w: Hrubieszów przez dzieje, Hrubieszów 1990, s. 21-41.

Szczygieł R., Powstanie miasta Krasnegostawu i jego dzieje w XV wieku, „Zapiski Krasnostawskie" 5, 2014, s. 7-20.

Szykuła A., Żygawski J., Szlak Lwów-Lublin. Geneza, zmiany przebiegu i funkcje do końca XIX wieku, w: Ziemiaństwo na Lubelszczyźnie IV. Ziemianie w podróży. Materiały IV sesji naukowej zorganizowanej w Muzeum Zamoyskich w Kozłówce $w$ dniach 8-10 października 2008 roku, t. 1, red. H. Łaszkiewicz, Lublin 2010, s. 369-390.

Ternes J., Ferro, igni et... peste. Zniszczenia wojenne i klęski elementarne $w$ Krasnymstawie $w 2$ połowie XVII wieku, „Zapiski Krasnostawskie” 4, 2013, s. 33-43.

Weymann S., Cta i drogi handlowe w Polsce piastowskiej, Poznań 1938.

Weymann S., Ze studiów nad zagadnieniem dróg $w$ Wielkopolsce od X do XVIII w., „Przegląd Zachodni” 1953, nr 6-8, s. 194-253.

Wyrobisz A., Handel w Solcu nad Wista do końca XVIII w. Przyczynki do historii rynku wewnętrznego $w$ Polsce przedrozbiorowej, $\mathrm{PH}$, t. 57, 1966, nr 1, s. $15-48$.

Wyrobisz A., Typy funkcjonalne miast polskich $w$ XVI-XVIII $w$., PH, t. 72, 1981, nr 1, s. 25-49.

Wyrobisz A., Zagadnienie upadku rzemiosta i kryzysu gospodarczego miast $w$ Polsce: wiek XVI czy XVII? ( $w$ zwiazku $z$ pracami Maurycego Horna, Skutki ekonomiczne najazdów tatarskich z lat 1605-1633 na Ruś Czerwona, Wrocław 1964; oraz, Rzemiosto miejskie województwa betskiego w pierwszej połowie XVII wieku: zagadnienie kryzysu gospodarczego Rzeczypospolitej szlacheckiej w XVII wieku, Wrocław 1966), PH, t. 58, 1967, nr 1, s. 132-138. Zimmer B., Miasta ziemi chetmskiej od XIII do pot. XIX w. w zarysie, Lublin 1993.

Сидорук Т.В., Соціально-економічний розвиток Ратненського староства y XVI-XVII cm. (1500-1674 pp.), Острог 2007, mps w zbiorach autora. 
Dariusz Wojnarski

Crafts and trade in Krasnystaw. Between prosperity and crisis (mid-sixteenth century - seventeenth century)

(Summary)

The article discusses the condition of Krasnystaw's crafts and trade from the mid-sixteenth century until the seventeenth century. It presents the main stage in the history of crafts and trade in the town, paying attention to the sectors in which the centre specialised and their connections with the regional and national market. The city experienced the peak of its development in the mid-sixteenth century, and the first harbingers of the future downturn became visible in the last quarter of the century. Krasnystaw was the capital of a starosty and the seat of the Bishops of Chełm. It took advantage of its beneficial location near important trade routes, royal privileges, and the good economic situation in the Commonwealth's Golden Age. Home to well-developed artisan production and, to a lesser extent, a commercial centre, Krasnystaw was a midsized city of regional importance. The subsequent century saw growing impoverishment of burghers, which was due to structural changes in the national economy undermining the former position of cities as well as an accumulation of natural disasters and wartime destruction. Foreclosed real estate was mostly taken over by the clergy; as a result, jurydykas were steadily expanding their territory. In addition, local craftsmen and merchants struggled to keep up with the competition from newly chartered urban centres, especially nearby Zamość. As a consequence, Krasnystaw lost its influence as a centre of trade and artisan production and subsequently lost a large part of its population. The first signs heralding a change in this negative trend could be noticed in the last quarter of the seventeenth century.

Dariusz Wojnarski - dr, nauczyciel akademicki, wykładał m.in. na Uniwersytecie Marii Curie-Skłodowskiej, Katolickim Uniwersytecie Lubelskim i w Państwowej Wyższej Szkole Zawodowej im. Szymona Szymonowica w Zamościu. Zainteresowania badawcze: historia gospodarcza, Ordynacja Zamojska, miasta Rusi Czerwonej w okresie nowożytnym, międzynarodowe stosunki gospodarcze.

Dariusz Wojnarski - dr, academic scholar teaching among others at the Maria Curie-Skłodowska University (UMCS), John Paul II Catholic University of Lublin (KUL), Szymon Szymonowic State School of Higher Education in Zamość. Research interests: economic history, Zamoyski Family Fee Tail (Ordynacja Zamojska), towns of Red Ruthenia in the modern period, international economic relations.

E-mail: voynarsky@wp.pl 